\title{
Review
}

\section{The role of sulfoglucuronosyl glycosphingolipids in the pathogenesis of monoclonal IgM paraproteinemia and peripheral neuropathy}

\author{
By Toshio ARIGA*1,† \\ (Communicated by Kunihiko SuZUKI, M.J.A.)
}

\begin{abstract}
In IgM paraproteinemia and peripheral neuropathy, IgM M-protein secretion by $\mathrm{B}$ cells leads to a $\mathrm{T}$ helper cell response, suggesting that it is antibody-mediated autoimmune disease involving carbohydrate epitopes in myelin sheaths. An immune response against sulfoglucuronosyl glycosphingolipids (SGGLs) is presumed to participate in demyelination or axonal degeneration in the peripheral nervous system (PNS). SGGLs contain a 3-sulfoglucuronic acid residue that interacts with anti-myelin-associated glycoprotein (MAG) and the monoclonal antibody anti-HNK-1. Immunization of animals with sulfoglucuronosyl paragloboside (SGPG) induced anti-SGPG antibodies and sensory neuropathy, which closely resembles the human disease. These animal models might help to understand the disease mechanism and lead to more specific therapeutic strategies. In an in vitro study, destruction or malfunction of the blood-nerve barrier (BNB) was found, resulting in the leakage of circulating antibodies into the PNS parenchyma, which may be considered as the initial key step for development of disease.
\end{abstract}

Keywords: IgM paraproteinemia and peripheral neuropathy, HNK-1/SGlcA epitope, sulfoglucuronosyl glycosphingolipids (SGGLs), anti-MAG/SGGL antibody, blood-never barrier (BNB)

\section{Introduction}

Glycosphingolipids (GSLs) are located primarily on plasma membranes and are particularly abundant in the nervous system. They are known to play important roles in biological functions, such as cellular differentiation, modulation of signal transduction, and immune reactions. Recent studies have

*1 Institute of Molecular Medicine and Genetics, Medical College of Georgia, Georgia Health Sciences University, Augusta, Georgia, USA.

$\dagger$ Correspondence should be addressed: T. Ariga, Institute of Molecular Medicine and Genetics, Medical College of Georgia, Georgia Health Sciences University, $112015^{\text {th }}$ Street, Augusta, Georgia 30912, USA (e-mail: tariga@georgiahealth.edu or toshio. ariga@yahoo.com).

Abbreviations: GSL: glycosphingolipid; SGGLs: sulfoglucuronosyl glycosphingolipids; SGPG: sulfoglucuronosyl paragloboside; SGLPG: sulfoglucuronosyl lactosaminyl paragloboside; BNB: blood-nerve barrier; MEC: microvascular endothelial cell; SGlcA: 3-sulfoglucuronic acid; GlcAT: glucuronyltransferase; SulT: sulfotransferase; mAb: monoclonal antibody; E: embryonic day; $\mathrm{P}$ : postnatal day; IVIg: intravenous immunoglobulin. GSL structures are abbreviated using the IUPAC-IUB recommendations ${ }^{135)}$ except ganglio-series gangliosides, which were abbreviated according to Svennerholm. ${ }^{136)}$ focused on the immunological properties of GSLs and their role in pathogenic mechanisms of several immune-mediated peripheral neuropathies, such as Guillain-Barré syndrome. ${ }^{1), 2)}$ This field has recently undergone remarkable expansion. ${ }^{3), 4)}$

In plasma cell dyscrasias, one clone of plasma cells developed from B lymphocytes multiplies excessively and produces a large quantity of a single type of monoclonal antibody (immunoglobulin), known as the IgM M-protein. Monoclonal gammopathy of undetermined significance is the most common plasma cell dyscrasia, accounting for more than $60 \%$ of these diseases. It is sometimes closely associated with malignant disorders such as multiple myeloma, Waldenstrom's macroglobulinemia, primary amyloidosis, and heavy-chain disease. These diseases are more common among older people. IgM paraproteins accumulate in serum or urine of approximately $1 \%$ of patients above 50 years of age, and its incidence increases to approximately $3 \%$ in patients above 70 years of age. The incidence of plasma cell dyscrasia is increased in AfricanAmerican male populations. ${ }^{5)}{ }^{-7)}$ In this review, I will describe the pathological role of certain GSLs that 
are specific for the PNS on IgM paraproteinemia and peripheral neuropathy.

IgM paraproteinemia and peripheral neuropathy

Approximately $10 \%$ of patients with plasma cell dyscrasia have associated peripheral neuropathies that occur 6-10 times more frequently in these patients than in age-matched controls; ${ }^{8), 9)}$ this disease is referred to $\operatorname{IgM}$ paraproteinemia and peripheral neuropathy. Clinical manifestations are distal symmetric sensory symptoms followed by motor weakness with progressive proximal involvement. The disease often shows slow progression of a demyelinating neuropathy, which can be demonstrated by performing nerve conduction studies or nerve biopsies, in addition to a variable degree of axonal loss associated with sensory ataxia and impaired gait. ${ }^{10), 11)}$ Most patients have chronic, slowly progressive demyelinating neuropathy, predominantly in sensory ataxia. ${ }^{12)-15)}$ Neurophysiological examination typically shows a widespread slowing of sensorimotor nerve conduction velocity with marked delay of distal latencies, suggesting that nerve fiber endings are particularly affected. ${ }^{16)}$

Although the pathogenesis of IgM paraproteinemia and peripheral neuropathy is unknown, there is evidence that deposits of excessive amounts of abnormal IgM M-proteins are found in patient's nerve biopsies, especially in the PNS myelin. ${ }^{17), 18)}$ The intraneural injection of $\operatorname{IgM}$ M-proteins into animals reveals demyelination in the sciatic nerve, ${ }^{19), 20)}$ suggesting that the IgM M-protein may play a causative role in the disease. ${ }^{21)-23)}$

Latov et $a{ }^{24)}$ first reported that IgM M-protein in a patient with sensorimotor neuropathy and IgM gammopathy reacted with an antigen in the PNS. In about $50-60 \%$ of the patients with neuropathy, the monoclonal IgM M-protein possesses an antibody activity against myelin components in the PNS. The myelin antigen was subsequently characterized to be MAG. ${ }^{25)}$ The epitope was later shown to be on the oligosaccharide moiety of MAG. ${ }^{26)}$ It also reacted with the mouse monoclonal antibody HNK-1, which recognized a surface antigen of natural killer cells. ${ }^{27)}$

Although about half of the IgM M-protein reacted with MAG, the pathogenic role was debatable since MAG is distributed in both the PNS and central nervous system (CNS); however, only peripheral nerve injury occurred in the disease. In this regard, much attention has been focused on the reactivity of the monoclonal IgM M-protein from patients with peripheral neuropathy and PNS- specific glycosphingolipids (GSLs). ${ }^{28)-30)}$ Indeed, at least two GSLs strongly reacted with IgM M-protein from patient sera, suggesting that they may be the true target antigens for potentially harmful IgM Mprotein in the disease. ${ }^{29)}$

\section{Characterization of PNS-specific} glycosphingolipids recognizing monoclonal IgM M-protein in patients with IgM paraproteinemia and peripheral neuropathy

Ilyas et al. ${ }^{26)}$ first reported that monoclonal IgM M-protein of patients with IgM paraproteinemia and peripheral neuropathy cross-reacted to acidic GSLs in the ganglioside fraction from human sciatic nerve.

Freddo et $a .^{29)}$ found that the reactive PNSspecific GSLs lacked sialic acid; therefore, they were not gangliosides. We ${ }^{31}$ isolated two acidic GSLs that bound to the IgM M-protein from human cauda equina by DEAE-Sephadex A-25, Iatrobeads, and high performance liquid column chromatographies. The major acidic GSL migrated between GM1 and GD1a and the minor acidic GSL migrated between GD1a and GD1b (Fig. 1). Their structures were elucidated by sugar analysis, enzymatic digestion, mild acid hydrolysis, permethylation, fast atom bombardment mass spectrometry, and nuclear magnetic resonance studies.

Gas-liquid chromatography analysis revealed that the acidic GSLs contained glucose, galactose, $\mathrm{N}$-acetylglucosamine, glucuronic acid (GlcA), and long-chain base with molar ratio of 1:2.01:1.07:0.73 and 0.96 for the major GSL, and 1:2.97:1.88:0.93, and 0.82 for the minor GSL, respectively. The major fatty acids of both GSLs were C16:0, C18:0. C18:1, C20:0, C22:0, C24:0, and C24:1. The long chain base was mainly C18:1 sphingosine.

Negative fast atom bombardment mass spectrometry gave the sugar sequence information in addition to the molecular weights. Their core structure was confirmed to be paragloboside by high-performance thin-layer chromatography-immunostaining using anti-paragloboside monoclonal antibody (mAb).

Both acidic GSLs lacked sialic acid but contained sulfated GlcA as their acidic moiety. The presence of GlcA in mammalian GSLs is very rare. We confirmed its presence in GSLs by capillary gasliquid chromatography-chemical ionization mass spectrometry using authentic $\beta$-D-GlcA. The sulfate group in GlcA was attached to the 3 position by periodate oxidation and permethylation-reduction studies. In this procedure the terminal sulfated 
a

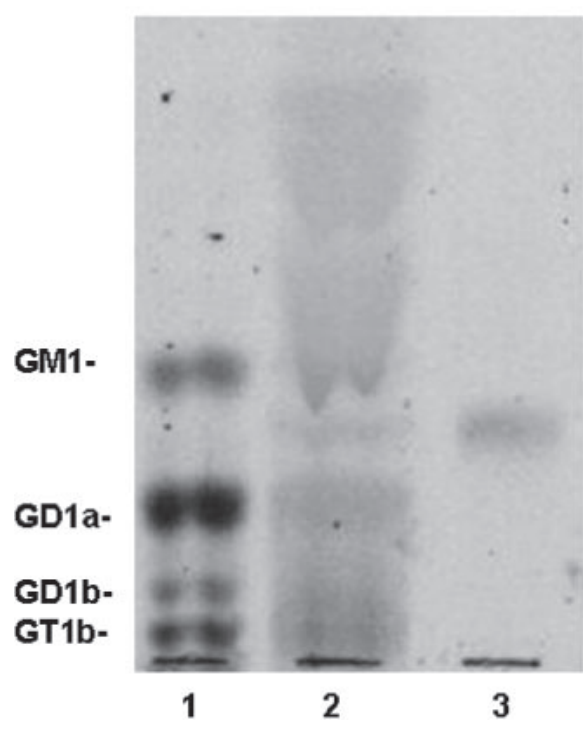

b

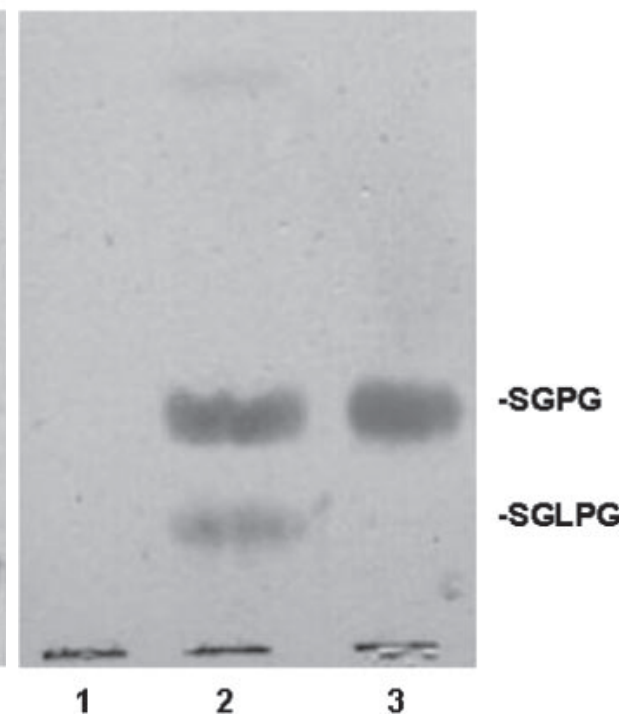

Fig. 1. Thin-layer chromatography-immunostaining of GSLs with serum from a patient with IgM paraproteinemia and peripheral neuropathy. Lane 1, bovine brain gangliosides; 2, acidic GSLs isolated from bovine cauda equine; 3, authentic standard sample of SGPG. Plate a was stained with orcinol-sulfuric acid reagent and plate b was immunostained with serum from patient with IgM paraproteinemia and peripheral neuropathy.

GlcA yielded a sulfated glucose residue. Subsequent acetolysis, reduction, and acetylation of the permethylated GSLs produced 2,4-di-O-methyl-1,3,5,6tetra-O-acethyl-glucitol, 2.3,6-tri-O-methyl-1.4-5-triO-acetylglucitol, 2.4.6-tri-O-methyl-1,3,5-tri-O-acetylgalactitol, and 3,6,-di-O-methyl-1,4,5-tri-O-acetyl1,3,5-tetra-O-acetyl-2-deoxy-2-N-methyl-acetoamidoglucitol. The structure of 2,4-di-O-methyl-1,3,5,6tetra-O-acethyl-glucitol was characterized by fragment ions at $\mathrm{m} / \mathrm{z} 43,117,129,159,189$, and 233 as detected by gas-liquid chromatography-electron ionization mass spectrometry. These results indicate that the sulfated group is attached to the 3 position of GlcA. Nuclear magnetic resonance studies confirmed that the paragloboside core structure and the further established sulfated GlcA were terminally linked and that all the sugars are $\beta$-linked.

These results indicate that the structures of the two acidic GSLs, named as sulfoglucuronosyl glycosphingolipids (SGGLs) are identified as follows: (a) $\operatorname{GlcA}(3$-sulfate $)(\beta 1-3) \operatorname{Gal}(\beta 1-4) \operatorname{GlcNAc}(\beta 1-3) \operatorname{Gal}(\beta 1$ $4)$-Glc $\left(\beta 1-1^{\prime}\right)$ ceramide or $\mathrm{IV}^{3} \mathrm{GlcA}(3$-sulfate $) \mathrm{nLcOse}_{4}{ }^{-}$ Cer (SGPG) and (b) GlcA(3-sulfate) $[(\beta 1-3) \operatorname{Gal}(\beta 1$ $4) \operatorname{GlcNAc}(\beta 1-3)]_{2} \operatorname{Gal}(\beta 1-4)-\operatorname{Glc}\left(\beta 1-1^{\prime}\right)$ ceramide or $\mathrm{VI}^{3} \mathrm{GlcA}\left(3\right.$-sulfate)nLcOse ${ }_{6} \mathrm{Cer}$ (SGLPG) as shown in Fig. 2. The structures of these SGGLs were independently confirmed by Chou et al. ${ }^{32), 33)}$ as well as by total chemical synthesis. ${ }^{34)-36)}$
The carbohydrate epitope recognizing in patients with IgM M-paraproteinemia and peripheral neuropathy and its expression in glycoproteins and neural adhesion molecules

The mouse monoclonal antibody anti-HNK-1 (Leu-7; VC1.1), which recognizes the surface antigen of natural killer cells, ${ }^{37)}$ is known to cross-react with MAG; ${ }^{38)}$ therefore the antigenic determinant for HNK1 is presumably present on MAG. ${ }^{26)}$ We have reported that HNK-1 and IgM M-protein both bind to acidic GSLs of the PNS. ${ }^{29)}$ Therefore, HNK-1/SGGL and human IgM M-protein from patients with neuropathy must share an affinity for a common epitope. ${ }^{29), 39)}$

SGPG was found to be extremely labile to acid. After treatment with $0.05 \mathrm{M}$ hydrochloric acid in methanol at room temperature, SGPG was converted to the lactone form of desulfated SGPG. After base treatment, the lactone form was converted to desulfated SGPG. Although desulfated SGPG was immunostained with patient's serum, neither the lactone form of desulfated SGPG or the methyl ester of desulfated SGPG were reactive, suggesting that the free carboxyl group, but not the sulfate group, in the terminal GlcA residue is necessary to bind IgM M-protein from neuropathy patients, ${ }^{31), 40)}$ whereas both the sulfate and carboxyl groups are required for reactivity with HNK-1.39),41) 
SGPG(sulfoglucuronosyl paragloboside; $\mathrm{IV}^{3} \mathrm{SO}_{4} \mathrm{GlcA}-\mathrm{nLcOse}{ }_{4} \mathrm{Cer}$ ) $\mathrm{SO}_{4}-3 \mathrm{GlcA} \beta$ 1-3Gal $\beta$ 1-4GlcNAc $\beta$ 1.3Gal $\beta$ 1.4Glc $\beta$ 1-1' $\mathrm{Cer}$

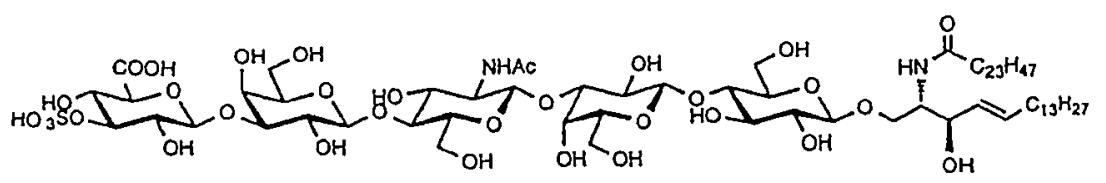

SGLPG(sulfoglucuronosyl lactosaminyl paragloboside; $\mathrm{VI}^{3} \mathrm{SO}_{4} \mathrm{GlcA}_{\mathrm{CLLCO}}{ }_{6} \mathrm{Cer}$ )
$\mathrm{SO}_{4}-3 \mathrm{GlcA} \beta$ 1-3 Gal $\beta$ 1-4GlcNAc $\beta$ 1-3 Gal $\beta$ 1-4 GlcNAc $\beta$ 1-3Gal $\beta$ 1-4Gle $\beta$ 1-1'Cer

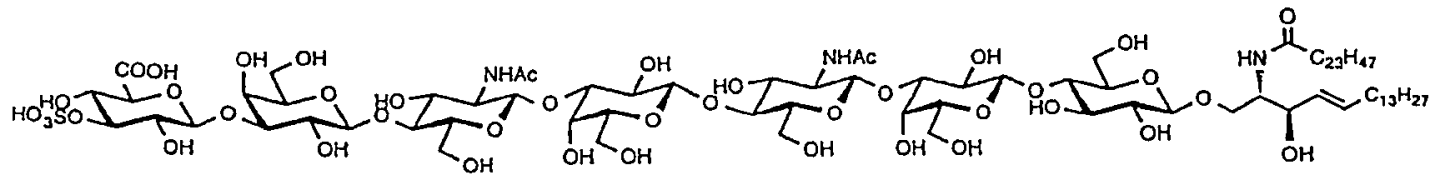

Fig. 2. Structures of SGGLs from human cauda equina.

To further define the precise structural requirement for this carbohydrate epitope, we tested 14 chemically synthesized SGGLs and their nonsulfated derivatives with defined carbohydrate chain lengths and aglycone structures, including ceramide, 2-(tetradecyl)hexadecyl residue, and 2-(trimethylsilyl)ethyl residue. ${ }^{42)}$ These synthetic SGGLs were tested for immunoreactivity with anti-HNK-1 antibody, VC1.1, mouse mAb NGR50, which was prepared using naturally occurring SGPG as the immunogen as described later, ${ }^{43)}$ and sera (LT and YT) from two patients with IgM paraproteinemia and demyelinating neuropathy using high-performance thin-layer chromatography-immunostaining and enzyme-linked immunoabsorbent assay. The mAb VC1.1 reacted with SGGL analogs containing a minimum of the two terminal sugars of 3-sulfoglucuronic acid (SGlcA)Gal-, but not with the nonsulfated derivatives of SGGLs nor with SGGLs having a modified ceramide structure. On the other hand, mAb NGR50 reacted only with SGPG and SGLPG. This suggests that mAb NGR50 reacts with an epitope that includes ceramide structure. The human patient serum LT reacted with all synthetic SGGLs except those with SE aglycone structure. On the other hand, another human patient serum YT, similar to the VC1.1, reacted with SGPG, SGLPG, and SGGL analogs containing a minimum of two terminal sugars of SGlcA-Gal-. All antibodies reacted more strongly with synthetic SGGLs with longer carbohydrate chains than those with shorter chains. These results indicate that, with some exceptions, anti-SGGL antibodies recognize a minimum of two sugars bearing the following structures, 3-sulfoglucuronosyl
11 -3galactosyl; SGlcA-Gal- and the aglycone ("ceramide") structure appear to play an important role for antibody-antigen interaction. ${ }^{3), 42)}$ In this regard, Schmitz et $a l^{44)}$ reported that both SGlcA and the neolactosyl core structures in synthetic SGGLs are essential for recognition of the L2/HNK-1 antibody and these structures may be responsible for the biological function of certain glycoconjugates.

Some of the carbohydrates on the cell surface have been shown to be associated with cell-cell recognition and adhesion. ${ }^{45), 46)}$ The HNK-1 carbohydrate epitope is known to be recognized as the surface antigen on a number of human lymphocytes, including natural killer cells ${ }^{37)}$ and are characteristically expressed on a series of cell adhesion molecules in MAG, including P0, PMP-22, NCAM, L1, J1, and $\mathrm{P}^{12), 15), 23), 30), 47)-49)}$ and also on some GSLs in the PNS. ${ }^{29), 31), 32)}$ Variability in the relative strength of the binding of the IgM M-proteins to these glycoconjugates as MAG, SGPG, P0 and PMP-22 has been described. ${ }^{50)}$ Shiina et $a l .{ }^{51)}$ reported that serum IgM M-proteins from 4 of the 12 patients with IgM paraproteinemia and peripheral neuropathy strongly immunostained the entire myelin, whereas serum IgM M-proteins from the remaining eight patients bound to a region surrounding the myelin sheath in the cross-section, suggesting that there are variabilities in the fine specificity of IgM M-proteins with anti-SGPG reactivities. They also reported that the reactivities against MAG and SGPG may play more important roles in the pathogenesis of IgM paraproteinemia and peripheral neuropathy than those against P0 and PMP-22. The HNK-1 or SGlcA epitope expressed on glycoconjugates modulate 
synaptic plasticity by affecting adhesive and antiadhesive properties ${ }^{52)}$ and cell adhesion, migration, and neurite outgrowth. ${ }^{53)-55)}$

In addition to HNK-1 (Leu-7 or CD57), specific antibodies against the SGlcA epitope, including Elec$39,{ }^{47)} \mathrm{NC}-1,{ }^{56)} \mathrm{BM}-89,{ }^{57)}$ and $\mathrm{VC} 1.1,{ }^{58)}$ have been reported. $\mathrm{We}^{43)}$ have produced the mouse $\mathrm{mAb}$ NGR50 by immunizing $\mathrm{C} 3 \mathrm{H} / \mathrm{HeN}$ inbred strain female mice with purified SGPG absorbed to acidtreated Salmonella minnesota mutant R595 and studied its antigenic specificity. Thin-layer chromatography immunostaining revealed that $\mathrm{mAb}$ NGR50 reacted specifically with SGPG and SGLPG, but not with the desulfated derivatives of SGGLs and other GSLs. Western blot analysis showed crossreactivity with human MAG and several glycoproteins in the $20-30 \mathrm{kDa}$ range, but not with rat MAG. Failure to react with rat MAG implies that the occurrence of the SGlcA epitope on glycoproteins is dependent upon the animal species. An immunocytochemical study of rat sciatic nerve using $\mathrm{mAb}$ NGR50 revealed positive staining in the outer surface of the myelin sheath and Schwann cells, as well as in the intervening connective tissues.

Jungalwala and co-investigators ${ }^{59), 60)}$ reported the presence of its binding protein, SBP-1, in the rat cerebellum and that its expression was developmentally regulated. ${ }^{59), 60)}$ During development of the rat cerebral cortex, the level of SBP-1 decreased after embryonic (E) day 18 to an almost undetectable level by postnatal $(\mathrm{P})$ day 10; whereas in the cerebellum, the expression of SBP-1 was maximal at P7. ${ }^{61)}$

Biosynthesis of SGGLs and cloning of key enzymes in the biosynthesis of HNK-1 epitope

Biosynthetically, at least four glycosyltransferases are required: lactosyl ceramide (LacCer; Gal $\left.\beta 1-4 \mathrm{Glc} \beta 1-1^{\prime} \mathrm{Cer}\right) \mathrm{N}$-acetylglucosaminyl transferase (LacCer-GlcNAcT) to form lactotriaosyl ceramide $\left(\mathrm{LcOse}_{3} \mathrm{Cer}\right) ; \mathrm{LcOse}_{3}$ Cer-galactosyl transferase ( $\mathrm{LcOse}_{3} \mathrm{Cer-GalT)}$ to form neo-lactotetraosyl ceramide (paragloboside, $\mathrm{nLcOse}_{4} \mathrm{Cer}$ ); $\mathrm{nLcOse}_{4}$ Cer-glucuronosyl transferase (GlcAT) to form glucuronosyl neolactotetraosyl ceramide $\left(\mathrm{IV}^{3} \mathrm{GlcA}-\mathrm{nLcO} \mathrm{se}_{4} \mathrm{Cer}\right)$; and $\mathrm{IV}^{3} \mathrm{GlcA}-\mathrm{nLcO} \mathrm{se}_{4}$ Cer-sulfotransferase (SulT) to form SGPG (IV ${ }^{3} \mathrm{GlcA}$ (3-sulfate) $\left.\mathrm{nLcOse}_{4} \mathrm{Cer}\right)$. Activities of these enzymes have been demonstrated in the brains of chickens and rodents; ${ }^{62)-66)}$ the key enzymes in the biosynthesis of HNK-1 epitope are $\beta 1,3-$ GlcAT, which transfers a GlcA to a terminal galactose, and SulT, which adds a sulfate group to the GlcA.
Das et al. ${ }^{62), 67)}$ first reported that glucuronyltransferase (GlcAT-1) in embryonic chicken brains catalyzed the in vitro biosynthesis in GLcA containing GSLs starting from neolactotetraosylceramide (nLcOse ${ }_{4} \mathrm{Cer}$ ) and neolactohexaosylceramide (nLcOse $\left.{ }_{6} \mathrm{Cer}\right)$. Chou et al. ${ }^{63)}$ also reported that the enzyme in the adult rat cerebral cortex catalyzed the transfer of GlcA from UDP-GlcA to the terminal galactose of the neolacto (type 2) series of GSLs to form $\beta$ 1-3-linked glucuronosyl neolacto-GSLs. The enzyme was highly specific for the neolacto series of acceptor GSLs, nLcOse ${ }_{4} \mathrm{Cer}, \mathrm{nLcOse}_{6}$-Cer, and neolactooctaosylceramide (nLcOse ${ }_{8} \mathrm{Cer}$ ). Considerable activity of GlcAT was present in the adult rat cerebral cortex, even though SGGLs almost completely disappeared from the cortex by P15. In the cerebellum, although the levels of SGGLs increased with development, the specific activity of GlcAT declined. ${ }^{68)}$

Oka et al. ${ }^{69)}$ found in rat brain extract two different GlcATs that were separated by UDP-GlcASepharose CL-6B column chromatography, designated as GlcAT-L and GlcAT-P. GlcAT-L was recovered predominantly in the effluent fraction and catalyzed the transfer of GlcA from UDP-GlcA to GSL acceptors. GlcAT-P was recovered in the eluting fraction and catalyzed the transfer of GlcA to glycoprotein acceptors, suggesting that GlcAT-P is associated with the biosynthesis of HNK-1 epitope on glycoproteins such as N-CAM and other cell adhesion molecules. ${ }^{69), 70)}$ GlcAT-P specifically recognized the N-acetyllactosamine (Gal $\beta 1-4 \mathrm{GlcNAc}$ ) structure at the nonreducing terminals of glycoprotein acceptor, whereas GlcAT-L had a similar activity to that reported by Das et al. ${ }^{62)}$ and Chou et al. ${ }^{63)}$ Further studies have demonstrated that GlcAT-L or GlcAT-D is active on both glycoproteins and GSLs in vitro. ${ }^{71), 72)}$ The GlcAT-P was highly specific to the terminal type II structure, Gal $\beta 1$ $4 \mathrm{GlcNAc}$, while the GlcAT-S recognized not only the type II structure, Gal $\beta 1-4 \mathrm{GlcNAc}$, but also the type I structure, Gal $\beta 1-3 \mathrm{GlcNAc} .{ }^{73)}$ These acceptor specificities were similar to those of the native enzymes. ${ }^{74), 75)}$ The GlcAT-D transferred a GlcA to not only type 2 (Gal $\beta 1-4 \mathrm{GlcNAc})$ but also type 1 (Gal/1-3GlcNAc) glycan chains, suggesting that the HNK-1 epitope expressed on type 1 glycan chain may occur, although the existence of such glycans has not previously been reported. The enzyme was localized specifically in the brain, and was barely detectable in other tissues, including sciatic nerve fibers, thymus, and liver. ${ }^{73)}$ Yavuz 
et al. ${ }^{76)}$ reported that GlcAT-P expressed on mouse brain was also expressed in E. coli cells along with other glycosyltransferases and showed activity for transfer of GlcA to neolactotetraose and neolactohexaose.

Some phospholipids were reported to stimulate the activities of glycosyltransferases, such as $\beta 1$ $4 \mathrm{GalT}^{77)}$ and $\alpha 2-3$ sialyltransferase. ${ }^{78)}$ GlcAT-P was activated dramatically in the presence of sphingomyelin. ${ }^{70)}$ In GlcAT-D, phosphatidylinositol and phosphatidylserine increased the enzymatic reaction by 4.4- and 2-3-fold, respectively, whereas phosphatidylcholine slightly decreased the rate. ${ }^{73)}$ Phosphatidyl inositol is specifically required for expression of the activity of the recombinant enzymes toward the GSL acceptor, paragloboside. ${ }^{79)}$

Terayama et al. ${ }^{80)}$ first isolated a cDNA clone encoding GlcAT-P from a rat brain by a PCR-based cloning method. The primary structure deduced from the cDNA sequence predicted a type II transmembrane protein with 347 amino acids. Mitsumoto et $a l .{ }^{81)}$ also cloned a cDNA encoding GlcAT-P from human brain that was $98.2 \%$ identical to rat GlcAT-P in amino acid sequence and demonstrated that the human GlcAT-P gene was located on chromosome 11q25. Transfection of the GlcAT-P cDNA into COS-1 cells not only induced expression of the HNK-1 epitope on the cell surface but also marked morphological changes of the cells, suggesting that the HNK-1 epitope is associated with a cell-substratum interaction. Further study of the gene indicated that the predicted amino acid sequence of mouse GlcAT-P was $96.2 \%$ and $98.2 \%$ identical to those of the rat and human enzymes, respectively. ${ }^{82)}$ Alternatively spliced isoforms of mouse GlcAT-P are present in the brain and encode two proteins that are identical throughout their length except for an additional 13 amino acids in the N-terminal cytoplasmic domain of the major form. The coding region of GlcAT-P was composed of 5 exons spanning approximately $6 \mathrm{~kb}$, and the GlcAT$\mathrm{P}$ gene was mapped to the $\mathrm{A} 4$ region of mouse chromosome 9 .

GlcAT might catalyze the transfer of GlcA to the Gal residue of proteoglycans. Kitagawa et al. ${ }^{83)}$ cloned a cDNA from human placenta, which encoded GlcAT-1 responsible for the biosynthesis of the glycosaminoglycan-protein linkage region, GlcA $\beta 1$ $3 \mathrm{Gal} \beta 1-3 \mathrm{Gal} \beta 1-4 \mathrm{xyl} \beta 1-\mathrm{O}-\mathrm{Ser}$, of the proteoglycan by a PCR strategy based on motifs conserved GlcAT-P into putative proteins. The amino acid sequence showed $43 \%$ identity to the rat GlcAT-P, and the highest sequence identity was found in the $\mathrm{COOH}$ terminal catalytic domain.

During a screening of a rat brain cDNA library using GlcT-P cDNA corresponding to the catalytic region of GlcAT-P as a probe, Seiki et al. ${ }^{72)}$ obtained a novel cDNA clone encoding a GlcAT-D, later named as GlcAT-S. The cDNA sequence contained an open reading frame encoding 324 amino acids, with type II transmembrane topology. The amino acid sequence revealed $49 \%$ homology to rat GlcAT$\mathrm{P}$. In this regard, using the RNA of rat E 13 brain as a template of reverse transcription-PCR and designing primers to the highly conserved regions found in the alignment of amino acid sequence of GlcAT-P and GlcAT-1, Shimoda et $a l .{ }^{71)}$ independently isolated a cDNA clone encoding a GlcAT-D, which was involved in the biosynthesis of the HNK-1 epitope on the neuronal cells. Imiya et al. ${ }^{84)}$ isolated a cDNA and genomic clones encoding the mouse GlcAT-S. The amino acid sequence of mouse GlcAT$\mathrm{S}$ was $98.1 \%$ identical to that of rat GlcAT-S. Northern blot analysis revealed that the mouse GlcAT-S transcript was specifically expressed in the nervous system. Moreover, the mouse GlcAT-S gene was composed of four exons spanning over more than 25 kilobase pairs. Southern blot analysis and chromosomal mapping indicated that the mouse GlcAT-S gene was a single copy gene and mapped to the A4-B region of mouse chromosome 1 . The GlcAT-S transcript was specifically expressed in the nervous system. The crystal structures of these GlcATs have been reported. ${ }^{85), 86)}$

Sulfotransferase (SulT) is also considered to be a key enzyme in the biosynthesis of the HNK-1 epitope. Subsequently, Bakker et al. ${ }^{87)}$ reported the isolation of a cDNA clone encoding SulT from rat brain by an expression cloning strategy that involved the cotransfection of GlcAT-P cDNA. The clone isolation predicts a protein of 356 amino acids, with characteristics of a type II transmembrane protein and with no sequence similarity to other known SulTs. The enzyme is expressed as a soluble fusion protein, and cell homogenate transfection with the full-length cDNA transfers a sulfate from a sulfate donor to acceptor substrates containing a terminal GlcA. The cloned cDNA was shown to induce HNK-1 reactivity in $\mathrm{CHOP}_{2}$ cells only in combination with a GlcAT, indicating that these two enzymes, together with common enzymes already present in the cells, are required and sufficient for the biosynthesis of the HNK-1 epitope on glycoproteins. 
Expression of glucuronyltransferases and sulfotransferase in mouse brain and rat embryos

Inoue et $a l . .^{52)}$ and Nagase et al. ${ }^{88)}$ reported different region-specific expression patterns of two GlcATs (GlcT-P and GlcAT-S) or GlcAT-D. In mouse brain, strong expression of GlcAT-P and moderate expression of GlcAT-S were observed in the neuronal cells of several nuclei of limbic-related regions and of the sensory system and the cerebellum. In rat day $\mathrm{P} 8$ cerebellum, GlcAT-S mRNA was expressed in the internal and external granule layers as well as the embryonic palladium and retina. On the other hand, the expression of GlcAT-P was mainly localized in the Purkinje cell layer. ${ }^{71)}$

The HNK-1 epitope was observed in a subpopulation of myotomal cells and migrating myoblasts in the limb bud. Nagase et al. ${ }^{88)}$ investigated the expression patterns of genes encoding two GlcATs (GlcAT-P, GlcAT-D) and SulT, which are required for biosynthesis of the HNK-1 epitope. In rat day $\mathrm{E}$ 11.5, the GlcAT-P gene was expressed in the nonmigrating longitudinal fibers, whereas the GlcAT-D gene was expressed in the migrating myoblasts in the limb bud. Thus, differential expression of GlcAT genes may relate to the epaxial/hypaxial or migrating/non-migrating myoblast lineages, whereas the expression of the SulT gene was ubiquitously observed in the embryo, which was confirmed by complete absence of in situ hybridization signal when the SulT sense probe was used. In our study, however, GlcAT-P expression did not show significant developmental regulation in mouse brains. In contrast, GlcAT-S showed a transient expression pattern from E14 to E18. ${ }^{89)}$ Expression of GlcAT-S is presumed to be involved in the transient expression of SGPG in developing mouse embryonic brains.

Yamamoto et al. ${ }^{90)}$ generated mice with targeted deletion of the GlcAT-P gene; the HNK-1 carbohydrate disappeared almost completely in GlcAT-Pdeficient mice, but a trace of HNK-1 immunoreactivity remained on the surfaces of the soma and proximal dendrites of a subset of neurons in some limited regions. These remaining HNK-1 carbohydrates in GlcAT-P-deficient mice were localized predominantly in the perineuronal nets and assumed to be synthesized by GlcAT-S, suggesting the possibility that the two GlcATs synthesize structurally and functionally different HNK1 carbohydrates in vivo. From this point of view, GlcAT-P-deficient mice constituted a useful tool for clarifying the structural and functional roles of the remaining the
HNK-1 carbohydrate epitope. Interestingly, the GlcAT-P - / - mice exhibited normal development of gross anatomical features; however, the adult mutant mice exhibited reduced long-term potentiation at hippocampal CA1 synapses and showed a defect in spatial memory formation. GlcAT-P-deficient mice showed impaired hippocampus-dependent spatial learning. Although HNK-1 plays an essential role in synaptic plasticity and memory formation, it remains unclear how $\mathrm{HNK}-1$ regulates these functions.

\section{Expression of SGGLs in tissues of the nervous system}

SGGLs are present mainly in the PNS tissues, cauda equina, and sciatic nerve, of human, bovine, cat, dog, and monkey. ${ }^{40), 91)}$ They were present in high concentrations and seemed to express almost equal amounts in these species. ${ }^{40)}$ They were also present in the sciatic nerve of rat, mouse, rabbit, guinea pig, and chicken, but in much lower concentrations. Therefore, the occurrence of SGGLs was speciesdependent, and higher in non-rodent mammals than in rodents. ${ }^{40), 68), 91)}$ SGGLs were absent in the CNS of adult brain from the same species. The concentration of SGLPG was about one-fifth of that for SGPG in most tissues. ${ }^{91)}$ Although SGGLs did not express in the spinal cord, ${ }^{68), 91)}$ they were expressed in brain stem and dura mater. ${ }^{91)}$ SGGLs were also expressed in human dorsal root ganglion, ${ }^{92)}$ and motor and sensory neurons in the PNS, ${ }^{93)}$ in comparable amounts as in the sciatic nerve. SGGLs were minor components in human sympathetic ganglion, ${ }^{92)}$ inner ear, ${ }^{94)}$ eighth nerve, ${ }^{94)}$ and optic nerve. ${ }^{95)}$ Interestingly, SGGLs were not detectable in the CNS myelin, ${ }^{92)}$ but expressed as minor components in rat Schwann cells, ${ }^{91)}$ Schwanoma, ${ }^{91)}$ several tumor cells of neural origin, ${ }^{96)}$ brain microvessels, ${ }^{41)}$ human umbilical veins, ${ }^{41)}$ bovine brain microvascular endothelial cells, ${ }^{97)}$ human brain microvascular endotherial cells, ${ }^{98)}$ peripheral nerve endothelial microvascular endothelial cells, ${ }^{99)}$ as well as in the neural crest cells of fish and birds in low amounts. ${ }^{100)}$ SGGLs were found in the adult goldfish brain. It is speculated from these observations that SGGLs have some role during neural cell differentiation and in regeneration. In the CNS of higher animals, neuronal differentiation is minimal after maturation. However, it is known that in fish brain and in the PNS, neural cell differentiation and regeneration is possible even in the adult. ${ }^{32)}$ SGGLs were present in the purified myelin fraction from cat PNS nerve, but their level 
Table 1. Concentration of SGGLs in the nervous system tissues

\begin{tabular}{|c|c|c|c|c|}
\hline Spicies & Tissue & SGPG & SGLPG & References \\
\hline \multirow[t]{17}{*}{ Human } & \multirow[t]{2}{*}{ Cauda equina } & 1.34 & 0.29 & Kohriyama et al., 1987 (91) \\
\hline & & 1.59 & - & Ariga et al., $1990(92)$ \\
\hline & Sciatic nerve & 0.85 & 0.22 & Ariga et al., 1990 (92) \\
\hline & Dorsal root ganglion & 1.02 & 0.18 & Ariga et al., 1990 (92) \\
\hline & Sympathetic ganglion & 0.04 & ND & Ariga et al., $1990(92)$ \\
\hline & Motoneurons & 0.85 & - & Yu et al., 1994 (93) \\
\hline & Sensory nerve & 0.93 & - & Yu et al., 1994 (93) \\
\hline & Optic nerve & 0.04 & - & Yoshino et al., 1993 (95) \\
\hline & Inner ear & 0.17 & 0.01 & Yamawaki et al., 1998 (94) \\
\hline & Eighth nerve & 1.58 & 0.42 & Yamawaki et al., 1998 (94) \\
\hline & Cultured microvascular endothlial cells & 0.06 & - & Kanda et al., 2004 (98) \\
\hline & Cultured umbilical vein endothlial cells & 0.05 & - & Miyatani et al., 1990 (41) \\
\hline & Spinal cord & $\mathrm{ND}$ & $\mathrm{ND}$ & Kohriyama et al., 1987 (91) \\
\hline & Cerebral cortex & ND & ND & Kohriyama et al., 1987 (91) \\
\hline & Cerebral white matter & ND & ND & Kohriyama et al., 1987 (91) \\
\hline & Adult cerebellum & $12.5^{*}$ & - & Chou et al., 1991 (68) \\
\hline & Fetal brain, 37 weeks of gestation & $7.5^{*}$ & - & Chou et al., 1991 (68) \\
\hline \multirow[t]{6}{*}{ Bovine } & Cauda equina & 0.77 & 0.27 & Kohriyama et al., 1987 (91) \\
\hline & Dura mater & 1.05 & 0.05 & Kohriyama et al., 1987 (91) \\
\hline & Brain microvascular endothelial cells, 7 days & 0.07 & - & Kanda et al., 1994 (97) \\
\hline & Brain mcrovascular endothelial cells, 14 days & 0.02 & - & Kanda et al., 1994 (97) \\
\hline & Pheripheral nerve microvascular endothelial cells & 0.08 & - & Kanda and Ariga, 2001 (99) \\
\hline & Spinal cord & ND & $\mathrm{ND}$ & Kohriyama et al., 1987 (91) \\
\hline \multirow[t]{8}{*}{ Rat } & Sciatic nerve & 0.09 & 0.02 & Kohriyama et al., 1987 (91) \\
\hline & Cortex, ED 19 & $11.2^{*}$ & - & Chou et al., 1991 (68) \\
\hline & Cortex, Adult & $0.5^{*}$ & - & Chou et al., 1991 (68) \\
\hline & Trigeminal nerve & $1.5^{*}$ & - & Chou et al., 1991 (68) \\
\hline & Brain stem & $2.0^{*}$ & - & Chou et al., 1991 (68) \\
\hline & Brain microvessels & 0.09 & - & Miyatani et al., 1990 (41) \\
\hline & Cerebral myelin & ND & ND & Miyatani et al., 1990 (41) \\
\hline & Schwanoma & 0.1 & 0.02 & Kohriyama et al., 1987 (91) \\
\hline Chiken & Sciatic nerve & 0.1 & 0.002 & Kohriyama et al., 1987 (91) \\
\hline Rabbit & Sciatic nerve & 0.02 & 0.002 & Kohriyama et al., 1987 (91) \\
\hline
\end{tabular}

$\mathrm{g} / \mathrm{mg}$ protein; *ng/mg dry weight of tissue; ND, not detected; — , not determined.

was not enriched in whole homogenate. ${ }^{40), 101)}$ SGGLs were present in the adult rodent cerebellum. SGGLs were localized specifically in Purkinje cells and their arbors or dendrites in the molecular layer. ${ }^{102)}$ However, they were not detected in the cerebella mice mutants of the Purkinje cell degeneration model, in which Purkinje cell loss was the primary defect. The loss of SGGLs in Purkinje cell-deficient mutants was specific, since most of the major lipids were not significantly affected and only the percentage composition of other lipids, such as sulfatides and gangliosides, were altered in adult cerebellum of the mutants. Other GlcA-containing GSLs, which do not contain the sulfate group, have been reported in insects such as Calliphora vicina and Tenebrio molitor ${ }^{103), 104)}$ (Table 1).

Subcellular localization studies of bovine spinal accessory nerve tissue, ${ }^{91)}$ human dorsal root ganglion, ${ }^{92)}$ and human sensory nerve of the $\mathrm{PNS}^{93)}$ have demonstrated that SGPG was relatively abundant in the axolemma-enriched fraction $(1.71-3.33 \mu \mathrm{g} / \mathrm{mg}$ protein) and myelin (1.34-1.63 $\mathrm{gg} / \mathrm{mg}$ protein).

\section{Developmental expression of SGGLs in rat and mouse brains}

SGGLs were expressed in selected regions of the CNS tissues of fetal, newborn, and adult rodents and their expression is developmentally regu- 
lated. ${ }^{68), 101), 105), 106)}$ In rat cerebral cortex, SGGLs were developmentally regulated and were maximally expressed at day E15, but undetectable between day of birth (P1) and P14 after birth. They were not present in the adult rat brain but expressed maximally in the subpopulation of differentiated neurons of embryonic brain during development, thus they may be considered as stage-specific antigens. ${ }^{66), 68)}$ Immunoreactivity in the cerebral cortex appeared first in the mantle layer of neural tube of day E10. Staining then appeared more strongly in the molecular layer (layer I) and subplate (layer III), and more faintly in the intermediate zone and cortical plate in E15. In postnatal age, the whole brain was almost uniformly stained. However, immunoreactivity gradually disappeared 3 to 4 weeks after birth, except in specific neuronal cell types. ${ }^{107)}$

SGGLs are also detected in the cerebellum even in adult rats. ${ }^{106)}$ The levels of SGGLs increased during postnatal development of the cerebellum, contrary to their diminishing expression in the cerebral cortex. Interestingly, the developmental profile of SGGLs in cerebellum appeared to be biphasic. The first phase appears near birth, and then the level decreases at P7. This pattern may reflect developmental events such as cellular migration and differentiation. Based on immunocytochemical studies of SGGLs, Bergmann glial fibers, the granular cell layer, and nascent white matter were stained at P2. Immunoreactivity of the granular cells was diminished drastically at P7, but remained constant in the white matter. Thereafter, the second phase of SGGL expression occurred at P10 and reached a maximum at $\mathrm{P} 20$; this phase may reflect the massive growth of dendritic trees in Purkinje cells. By P15, the expression of SGGLs was greatly reduced except in the molecular layer, where the immunostaining persisted until adulthood. Therefore, SGGLs may serve as regulatory markers of cellular differentiation in the cerebellum. In the adult rat cerebellum, Purkinje cell dendritic trees of the molecular layer and synapses of the deep cerebral layer were strongly stained, but not in the granular cell layer or the white matter. ${ }^{108)}$ The high level of SGGLs remaining in Purkinje cells in adulthood suggests that SGGLs may play an integral role in Purkinje cell function. ${ }^{106)}$

In mouse embryos, the SGlcA epitope, detected using HNK-1 antibody, appeared at the early stages of E8.5 and E10.5. ${ }^{101)}$ Immunoreactivity against the HNK-1 epitope appeared in neuroepithelial cells prior to axonal outgrowth and along the walls of the early neural tube. This expression pattern suggests that the SGlcA epitope may be associated with the organization of early neuronal setting and axonal growth patterns, ${ }^{101)}$ and a further study indicated that SGPG was expressed at E16. ${ }^{89)}$

In rat PNS, the concentration of SGGLs increases with age and then declines slightly. The rate of increase in the level of SGGLs between day 5 to 20 was similar to the rate of deposition of myelin in the nerve. The rate of accretion of SGGLs was rapid for the first P30 days and plateaus at P40-60. This developmental pattern appeared to coincide with the process of myelination. ${ }^{68), 109)}$ In the mouse sciatic nerve, immunoreactivity against the HNK-1 epitope appeared first in unmyelinated fibers until P21, and strongly in myelinated fibers at 8 weeks. ${ }^{110)}$

\section{Experimental animal models of IgM paraproteinemia and peripheral neuropathy by sensitization of animals with SGPG}

In IgM paraproteinemia and peripheral neuropathy, studies on nerve biopsy from patients have revealed IgM deposits only in the PNS myelin and moderate demyelination with widening of the myelin lamellae. The IgM M-protein deposits are found in myelin with wide spacing of lamellae, which is the hallmark of this form of neuropathy. 12),15),111),112) Moreover, direct injection of anti-SGGL/MAG antibody into cat sciatic nerve resulted in demyelination, which was associated with complement deposition. ${ }^{19), 113)}$ Thus, an antibody-dependent complement-mediated mechanism is presumed to participate in the pathogenesis of this autoimmune disease. To further clarify the pathogenic role of SGGLs, we sensitized rabbits and Lewis rats with highly purified SGPG. ${ }^{20), 114)-116)}$

In rabbit, anti-SGPG antibody titers in sera were detected 2 to 4 weeks after the initial inoculation and reached a maximum 6 to 8 weeks postinoculation. The animals showed weight loss, sluggishness in righting response from the outstretched position, and a slight to mild weakness predominantly in their hind feet 2 to 5 weeks postinoculation. Electrophysiological studies revealed slightly diminished conduction velocity and conduction block in the sciatic nerves of the SGPGinoculated rabbits. Immunization of rabbits with purified SGPG produced mild neurological symptoms and electrophysiological dysfunction. ${ }^{114)}$ This finding strongly suggests the involvement of SGPG in the process of demyelination. 
a

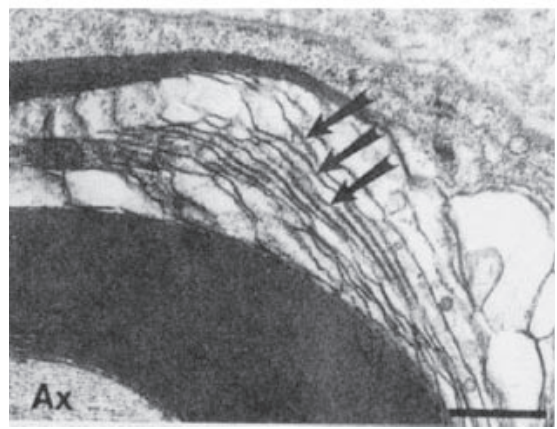

b

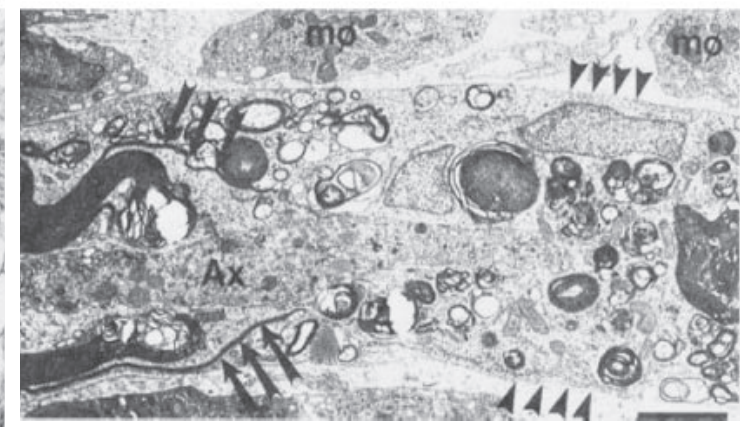

Fig. 3. Electron micrographs of rat sciatic nerve (a) $3 \mathrm{~h}$ and (b) 4 days after intraneural injection of anti-SGPG antibodies. (a) A large myelinated axon (Ax) with disintegrating leaflets of myelin (arrows), primarily along the intraperiod line. (b) An electron micrograph of the nodal region of an axon $(\mathrm{Ax})$. To the left, normal appearing paranodal myelin is being stripped away by insinuating macrophage $(\mathrm{m} \varphi)$ processes (arrows) from a degenerating axon (Ax). Numerous macrophages are present in the endoneurial connective tissues. Scale bars: $0.5 \mu \mathrm{m}$ (a), $2.5 \mu \mathrm{m}$ (b).

In Lewis rats, anti-SGPG antibody titers in the sera were detected 2 to 4 weeks after injection and reached a maximum 8 weeks post-inoculation. Interestingly, anti-SGLPG antibodies were detected at 6 weeks and reached a maximum 12 weeks postinoculation. Electrophysiological examination of the sciatic nerves revealed nerve conduction abnormalities that consisted of a conduction block and mild decrease in conduction velocity. ${ }^{116)}$ In addition, sensitization of rats with SGPG induced minor but clear clinical signs of neuropathy, consisting of mild tail muscle tone loss and walking disabilities. Morphological studies showed (a) axonal changes in the lateral aspects of the dorsal columns in the spinal cord; and (b) damage to the endothelial cells in the spinal cord, which suggested a breakdown of the blood-brain barrier $(\mathrm{BBB}) .^{20}$ ) In this regard, we reported that SGPG was present in the microvessels of adult rat brain. ${ }^{41)}$ Thus, the present finding supports our hypothesis that disruption to the capillaries, which may be induced by the circulating anti-SGPG antibodies, may contribute to subsequent nerve damage. ${ }^{20)}$ Interestingly, intraneural injection of the rat anti-SGPG antibody with guinea pig complement into the sciatic nerve of Lewis rats revealed extensive demyelination and axonal degeneration, along with mild to moderate clinical symptoms. Morphologically, vesiculation and loosening of the myelin sheath were observed $8 \mathrm{~h}$ post-injection, followed by extensive demyelination and macrophage infiltration after 4 days $^{115)}$ (Fig. 3). Since rat MAG does not bear the SGlcA epitope, it supports the concept that SGGLs may serve as primary target antigens in experimental IgM paraproteinemia and demyelinating neuropathy.
Ilyas et al. ${ }^{117)}$ reported that four cats immunized with SGPG developed clinical signs of sensory neuropathy within 11 months after initial immunization. All cats demonstrated characteristics of unsteadiness, falling, hind limb weakness and ataxia. In two cats, the ataxia and hind limb paralysis were so severe that the animals had to be euthanized. Pathological examination revealed sensory ganglionitis with inflammatory infiltrates in the dorsal root ganglia. No overt signs of pathology were noted in the examined roots or nerves. High-titer antiSGPG antibodies were detected in all 4 cats immunized with SGPG but not in the three control cats. This study suggests that these anti-SGPG antibodies play a role in the pathogenesis of this neuropathy. It has suggested that immunization of cats with SGPG induces anti-SGPG antibodies along with a sensory neuropathy that closely resembles human disease.

These animal models might help us understand the disease mechanism and lead to more specific therapeutic strategies.

\section{Pathological role of SGGLs on IgM paraproteinemia and peripheral neuropathy}

1. Interaction between SGGLs and bloodnerve barrier. Although the primary causal role of humoral immunity has been postulated in IgM paraproteinemia and peripheral neuropathy, ${ }^{20), 114)}$ the mechanism by which large molecules such as immunoglobulins can traverse the $\mathrm{BBB}$ or $\mathrm{BNB}$ to enter the endoneurium is not fully understood. ${ }^{99}$ However, in this disease, the destruction or malfunction of the $\mathrm{BBB}$ or the $\mathrm{BNB}$ results in leaking of 
circulating antibodies into the PNS parenchyma. This has been considered as the initial key step for the development of disease process. Since endoneurial microvascular endotherial cells (MECs) are one of the cardinal components making up the structural basis of the $\mathrm{BBB} / \mathrm{BNB}$, knowledge on the cellular characteristic of MECs using cell culture techniques may provide new insights regarding the pathogenetic mechanism of this immune-mediated neuropathy.

To test the hypothesis that circulating antibodies trigger permeability changes in the microvascular structure, we $\mathrm{w}^{97}$ established an in vitro model of the BNB by coculturing a bovine MEC monolayer and rat astrocytes in Transwell chambers. We analyzed the effect of anti-IgM SGPG antibody obtained from a patient with IgM paraproteinemia and demyelinative peripheral neuropathy against cultured bovine MECs. Permeability studies revealed that the antibody facilitated the leakage of [carboxy${ }^{14} \mathrm{C}$-inulin and ${ }^{125}$ I-labeled human $\operatorname{IgM}$ through bovine MEC monolayers. A direct cytotoxicity of this antibody against bovine MECs was also shown by a leakage study using $\left[{ }^{51} \mathrm{Cr}\right]$-incorporated bovine MECs. This cytotoxicity depended on the concentration of the IgM antibody, and was almost completely blocked by preincubation with the pure antigen, SGPG. This study strongly supports the hypothesis that immunological insults against bovine MEC-bound SGGLs induce the destruction or malfunction of the BNB, which results in penetration of the immunoglobulin molecule that attaches to the peripheral nerve parenchyma. It is also an intriguing possibility that SGGLs, which bear the same carbohydrate epitope as several cell-adhesion glycoproteins, may actually participate in the formation of the $\mathrm{BBB} / \mathrm{BNB}$ and the maintenance of barrier function. This study showed that bovine MECs and the peripheral nervous tissues shared many GSLs, including SGPG, as common antigens; hence, the presumed cascade of pathological processes-immunological function of the BNB is: (a) increased permeability across the BNB, (b) leakage of immunoglobulins into the endoneurial space, and (c) subsequent immunological attack of peripheral myelin and axon, ultimately leading to their destruction, which can be logically explained in those patients with anti-GSL antibody. In SGPG sensitive rat study, damage in the capillaries was induced in the dorsal horn of the spinal cord lumbar region, ${ }^{20)}$ suggesting the damage to endothelial cells increases the leakage of plasma proteins into the nerve parenchyma. However, it is not clear how immunological insults against bovine MECs actually occur in this disease. There have been few studies on the pathological changes of endothelial cells in IgM neuropathy. Meier et al. ${ }^{118)}$ reported that the gap between the adjacent endoneurial cells are enlarged in IgM neuropathy, and Powell et al. ${ }^{119)}$ showed microvascular changes, including endothelial cytoplasmic enlargement occasionally obliterating the vessel lumen, and intracytoplasmic actin-like filaments in dysglobulinemic neuropathies. Detailed characterization of the antibodies was not performed. In both reports, pathological changes in endothelial cells were completely different from those of acute inflammatory changes, but minimal presumably due to the deposition of circulating immune complexes typically observed in vessels in collagen disease with vasculitis such as periarteritis nodosa. ${ }^{120)}$

2. Inflammatory effect of SGGLs on microvascular endothelial cells that may be involved in the pathogenesis of IgM paraproteinemia and peripheral neuropathy Although the functional roles of SGGLs are not clear, they are able to support cell adhesion of Schwann cells in vitro ${ }^{121)}$ and they may have implications in neural cell adhesion. ${ }^{54)}$

The most interesting aspect of the regulated expression of SGGLs in bovine MECs is the induction of their synthesis by proinflammatory cytokines. Treatment of bovine MECs with interleukin (IL)$1 \beta$, a proinflammatory cytokine, was shown to induce accumulation of SGGLs. ${ }^{122}$ ) The SGPG content in bovine MECs increased 8 fold after stimulation for $4 \mathrm{~h}$; this resulted in an enhanced attachment of human lymphocytes on IL- $1 \beta$-activated bovine MEC monolayer surface. Further studies indicate that inflammatory cytokines, such as tumor necrosis factor (TNF)- $\alpha$ and IL- $1 \beta$ stimulate the GlcAT-P and GlcAT-S genes and elevate the SGPG concentration in cerebromicrovascular endothelial cells, SV-HCEC, promoting T cell adhesion. ${ }^{123)}$ In siRNA HNK-1 ${ }^{\text {ST }}$ (siHNK-1)-transfected cells, SGPG expression was down-regulated after stimulation in addition to reducing $\mathrm{T}$ cell adhesion. In addition, upregulation of GlcAT genes in the cells was observed after cytokine stimulation mediated by $\mathrm{NF} \kappa \mathrm{B}$ signaling; controversially, inhibition of SGPG expression by siHNK-1 intercepted the NF $\kappa \mathrm{B}$ activity. ${ }^{124)}$

Selectins are known to be involved in the interaction between leukocytes and vascular endothelial cell adhesion, leading to lymphocyte homing, platelet binding, and neutrophil extravasation. ${ }^{125)}$ Needham and Schnaar ${ }^{126)}$ have reported that L- 


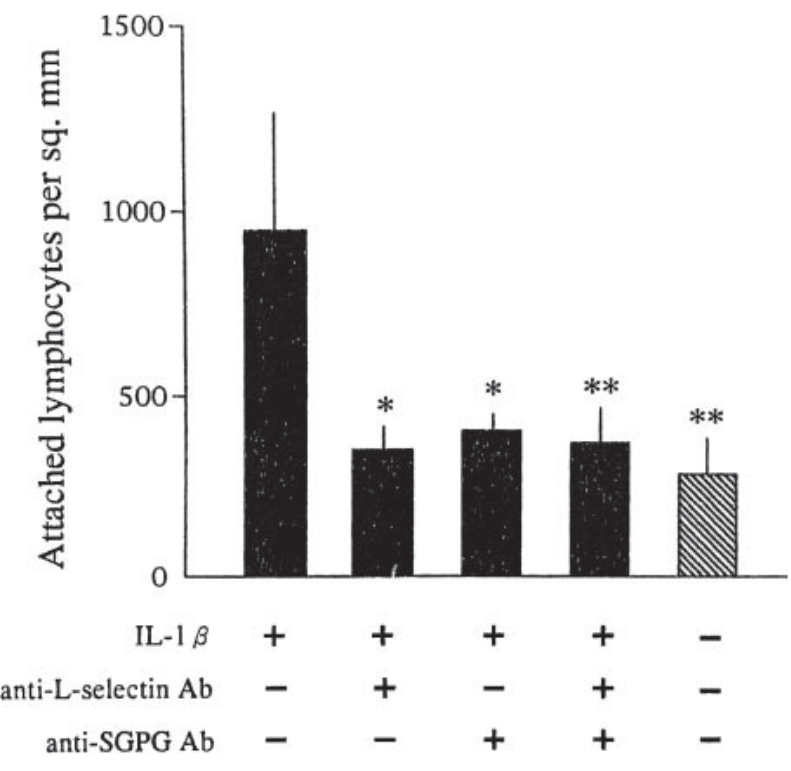

Fig. 4. Effect of anti-L-selectin and anti-SGPG antibodies on the adhesion of human lymphocyes. Filled bars represent IL-1 $\beta$ activated bovine MECs and the hatched bar represents the nonactivated bovine MEC monolayer. Preincubation with antiL-selectin and/or anti-SGPG antibody significantly reduced the attachment of human lymphocytes onto the bovine MEC monolayer $\left({ }^{*} P<0.05\right.$; $\left.{ }^{* *} P<0.001\right)$. Error bars indicate the SD.

and P-selectins bind to a surface adsorbed with SGGLs in a $\mathrm{Ca}^{+2}$-independent manner, but not with E-selectin. Interestingly, we ${ }^{122)}$ have found that a significantly larger number of human lymphocytes attach to the IL- $1 \beta$-stimulated bovine MECs than to the unstimulated bovine MECs. Interestingly, attachment of human lymphocytes to the IL- $1 \beta$ activated bovine MEC cells can be blocked either by incubation of the human lymphocytes with an antiL-selectin antibody or by application of an antiSGPG antibody to the bovine MECs (Fig. 4). In this study, SGPG may act as an important ligand for Lselectin for the regulation of the attachment of activated lymphocytes, subsequently allowing cytotoxic lymphocytes to enter into the nervous system parenchyma in inflammatory diseases of the PNS. Whether L-selectin is involved in any SGGL-mediated cell adhesions is not clear. L-selectin-mediated attachment of lymphocytes to myelinated tracts of the CNS was reported. ${ }^{127)}$ In this regard, it may support the selective adhesion of a desired subpopulation of leukocytes expressing L- or P-selectin. SGGLs on the surface of MECs may play an important role in inflammatory IgM paraproteinemia and peripheral neuropathy of the PNS. The presence of SGGLs on brain microvascular endothelium may implicate these molecules in leukocyte trafficking to the nervous system and elsewhere. ${ }^{126)}$

Hence, an immunological block of SGlcA epitope by IgM M-protein may result in loss of cellular interconnection and disruption of barrier function. Our overall results strongly support the concept that immunological insults against bovine MECs induce the destruction or malfunction of the $\mathrm{BBB} / \mathrm{BNB}$, resulting in the penetration of immunoglobulin molecules and attack of the peripheral nerve parenchyma.

\section{Therapeutic strategies in patients with IgM} paraproteinemia and peripheral neuropathy

Based on evidence regarding the pathogenicity of anti-MAG/SGGL antibodies, therapeutic effects have been documented reducing circulating IgM protein or anti-MAG/SGGL antibodies by removal (plasmapheresis or plasma exchange), inhibition (intravenous immunoglobulin, IVIg), or reduction of synthesis (corticosteroid, immunosuppressive, cytotoxic agents or interferon- $\alpha$ etc). ${ }^{128)}$ In an earlier study, reducing the IgM M-protein concentration by plasmapheresis or plasma exchange has been reported to ameliorate thesymptoms of patients. ${ }^{24}$ ) Plasma exchange was temporarily effective in approximately half of the patients both alone and in combination with other therapies. ${ }^{11)}$ Corticosteroids alone had no effect, but approximately half of the patients responded to corticosteroids given in association with other therapies. ${ }^{11)}$ IVIg was effective in half of the patients. Patients who had anti-MAG IgM antibodies, showed significant improvement at 4 weeks with IVIg compared with placebo. ${ }^{129)}$ Some agents, such as interferon- $\alpha,{ }^{130)}$ chlorambucil, ${ }^{11)}$ cyclophosphamide, ${ }^{131)}$ and Rituximab (monoclonal antibody against CD20 antigen) improved the sensory ataxia. ${ }^{132), 133)}$ A plausible possibility is that blockage of leukocyte/endothelial cell connections by applying excess amounts of polysaccharides ${ }^{134)}$ or by administration of monoclonal antibodies to block these oligosaccharide epitopes might be an effect therapeutic strategy. ${ }^{97)}$

\section{Acknowledgements}

I am grateful to Dr. Robert K. Yu, Professor of Georgia Health Sciences University, and to the coinvestigators who contributed to the experimental work that has been carried out in his laboratory. I am also grateful to Dr. Rhea-Beth Markowitz, Georgia Health Sciences University, for her skillful editorial assistance. 


\section{References}

1) Ariga, T. and Yu, R.K. (2005) Antiglycolipid antibodies in Guillain-Barré syndrome and related diseases: review of clinical features and antibody specificities. J. Neurosci. Res. 80, 1-17.

2) Willison, H.J. and Yuki, N. (2002) Peripheral neuropathies and anti-glycolipid antibodies. Brain 125, 2591-2625.

3) $\mathrm{Yu}$, R.K. and Ariga, T. (1998) The role of glycosphingolipids in neurological disorders. Mechanisms of immune action. Ann. N. Y. Acad. Sci. 845, 285-306.

4) Kaida, K., Ariga, T. and Yu, R.K. (2009) Antiganglioside antibodies and their pathophysiological effects on Guillain-Barré syndrome and related disorders - a review. Glycobiology 19, 676-692.

5) Kyle, R.A. and Rajkumar, S.V. (2003) Monoclonal gammopathies of undetermined significance: a review. Immunol. Rev. 194, 112-139.

6) Kelly, J.J. (2008) Peripheral neuropathies associated with monoclonal gammopathies of undetermined significance. Rev. Neurol. Dis. 5, 14-22.

7) Groves, F.D., Travis, L.B., Devesa, S.S., Ries, L.A. and Fraumeni, J.F. Jr. (1998) Waldenstrom's macroglobulinemia: incidence patterns in the United States, 1988-1994. Cancer 82, 1078-1081.

8) Kelly, J.J. Jr., Kyle, R.A., O'Brien, P.C. and Dyck, P.J. (1981) Prevalence of monoclonal protein in peripheral neuropathy. Neurology 31, 1480-1483.

9) Dalakas, M.C. (2010) Pathogenesis and Treatment of Anti-MAG Neuropathy. Curr. Treat. Options Neurol. 12, 71-83.

10) Latov, N., Hays, A.P. and Sherman, W.H. (1988) Peripheral neuropathy and anti-MAG antibodies. Crit. Rev. Neurobiol. 3, 301-332.

11) Nobile-Orazio, E., Meucci, N., Baldini, L., Di Troia, A. and Scarlato, G. (2000) Long-term prognosis of neuropathy associated with anti-MAG IgM Mproteins and its relationship to immune therapies. Brain 123 (Pt. 4), 710-717.

12) Latov, N. (1995) Pathogenesis and therapy of neuropathies associated with monoclonal gammopathies. Ann. Neurol. 37 (Suppl. 1), S32-S42.

13) Van den Berg, L., Hays, A.P., Nobile-Orazio, E., Kinsella, L.J., Manfredini, E., Corbo, M., Rosoklija, G., Younger, D.S., Lovelace, R.E., Trojaborg, W., Lange, D.E., Goldstein, S., Delfiner, J.S., Sadiq, S.A., Sherman, W.H. and Latov, N. (1996) Anti-MAG and anti-SGPG antibodies in neuropathy. Muscle Nerve 19, 637-643.

14) Nobile-Orazio, E. (2004) IgM paraproteinaemic neuropathies. Curr. Opin. Neurol. 17, 599-605.

15) Quarles, R.H. and Weiss, M.D. (1999) Autoantibodies associated with peripheral neuropathy. Muscle Nerve 22, 800-822.

16) Kaku, D.A., England, J.D. and Sumner, A.J. (1994) Distal accentuation of conduction slowing in polyneuropathy associated with antibodies to myelin-associated glycoprotein and sulphated glucuronyl paragloboside. Brain 117 (Pt. 5), 941-947.

17) Vallat, J.M., Jauberteau, M.O., Bordessoule, D., Yardin, C., Preux, P.M. and Couratier, P. (1996) Link between peripheral neuropathy and monoclonal dysglobulinemia: a study of 66 cases. J. Neurol. Sci. 137, 124-130.

18) Ropper, A.H. and Gorson, K.C. (1998) Neuropathies associated with paraproteinemia. N. Engl. J. Med. 338, 1601-1607.

19) Hays, A.P., Latov, N., Takatsu, M. and Sherman, W.H. (1987) Experimental demyelination of nerve induced by serum of patients with neuropathy and an anti-MAG IgM M-protein. Neurology 37, 242256.

20) Maeda, Y., Brosnan, C.F., Miyatani, N. and Yu, R.K. (1991) Preliminary studies on sensitization of Lewis rats with sulfated glucuronyl paragloboside. Brain Res. 541, 257-264.

21) Steck, A.J., Murray, N., Dellagi, K., Brouet, J.C. and Seligmann, M. (1987) Peripheral neuropathy associated with monoclonal $\operatorname{IgM}$ autoantibody. Ann. Neurol. 22, 764-767.

22) Melmed, C., Frail, D., Duncan, I., Braun, P., Danoff, D., Finlayson, M. and Stewart, J. (1983) Peripheral neuropathy with IgM kappa monoclonal immunoglobulin directed against myelinassociated glycoprotein. Neurology 33, 13971405.

23) Nobile-Orazio, E., Manfredini, E., Carpo, M., Meucci, N., Monaco, S., Ferrari, S., Bonetti, B., Cavaletti, G., Gemignani, F., Durelli, L., Barbieri, S., Allaria, S., Sgarzi, M. and Scarlato, G. (1994) Frequency and clinical correlates of anti-neural IgM antibodies in neuropathy associated with IgM monoclonal gammopathy. Ann. Neurol. 36, 416-424.

24) Latov, N., Sherman, W.H., Nemni, R., Galassi, G., Shyong, J.S., Penn, A.S., Chess, L., Olarte, M.R., Rowland, L.P. and Osserman, E.F. (1980) Plasma-cell dyscrasia and peripheral neuropathy with a monoclonal antibody to peripheral-nerve myelin. N. Engl. J. Med. 303, 618-621.

25) Braun, P.E., Frail, D.E. and Latov, N. (1982) Myelin-associated glycoprotein is the antigen for a monoclonal IgM in polyneuropathy. J. Neurochem. 39, 1261-1265.

26) Ilyas, A.A., Quarles, R.H., MacIntosh, T.D., Dobersen, M.J., Trapp, B.D., Dalakas, M.C. and Brady, R.O. (1984) IgM in a human neuropathy related to paraproteinemia binds to a carbohydrate determinant in the myelin-associated glycoprotein and to a ganglioside. Proc. Natl. Acad. Sci. U.S.A. 81, 1225-1229.

27) McGarry, R.C., Helfand, S.L., Quarles, R.H. and Roder, J.C. (1983) Recognition of myelin-associated glycoprotein by the monoclonal antibody HNK-1. Nature 306, 376-378.

28) Ilyas, A.A., Quarles, R.H. and Brady, R.O. (1984) The monoclonal antibody HNK-1 reacts with a human peripheral nerve ganglioside. Biochem. 
Biophys. Res. Commun. 122, 1206-1211.

29) Freddo, L., Ariga, T., Saito, M., Macala, L.C., Yu, R.K. and Latov, N. (1985) The neuropathy of plasma cell dyscrasia: binding of IgM M-proteins to peripheral nerve glycolipids. Neurology 35, 1420-1424.

30) Quarles, R.H., Ilyas, A.A. and Willison, H.J. (1986) Antibodies to glycolipids in demyelinating diseases of the human peripheral nervous system. Chem. Phys. Lipids 42, 235-248.

31) Ariga, T., Kohriyama, T., Freddo, L., Latov, N., Saito, M., Kon, K., Ando, S., Suzuki, M., Hemling, M.E., Rinehart, K.L. Jr., Kusunoki, S. and Yu, R.K. (1987) Characterization of sulfated glucuronic acid containing glycolipids reacting with IgM M-proteins in patients with neuropathy. J. Biol. Chem. 262, 848-853.

32) Chou, D.K., Ilyas, A.A., Evans, J.E., Costello, C., Quarles, R.H. and Jungalwala, F.B. (1986) Structure of sulfated glucuronyl glycolipids in the nervous system reacting with HNK-1 antibody and some IgM paraproteins in neuropathy. J. Biol. Chem. 261, 11717-11725.

33) Chou, D.K., Schwarting, G.S., Evans, J.E. and Jungalwala, F.B. (1987) Sulfoglucuronyl-neolacto series of glycolipids in peripheral nerves reacting with HNK-1 antibody. J. Neurochem. 49, 865873.

34) Nakano, T., Ito, Y. and Ogawa, T. (1993) Synthesis of sulfated glucuronyl glycosphingolipids; carbohydrate epitopes of neural cell-adhesion molecules. Carbohydr. Res. 243, 43-69.

35) Isogai, Y., Ishida, H., Kiso, M. and Hasegawa, A. (1996) Synthetic studies on sialoglycoconjugates 90: Total synthesis of sulfated glucuronyl paraglobosides. J. Carbohyd. Chem. 15, 1001-1023.

36) Chevalier, R., Colsch, B., Afonso, C., Baumann, N., Tabet, J.-C. and Mallet, J.-M. (2006) Synthetic sulfated glucuronosyl paragloboside (SGPG) and its use for the detection of autoimmune peripheral neuropathies. Tetrahedron 62, 563-577.

37) Abo, T. and Balch, C.M. (1981) A differentiation antigen of human NK and K cells identified by a monoclonal antibody (HNK-1). J. Immunol. 127, 1024-1029.

38) Murray, N. and Steck, A.J. (1984) Indication of a possible role in a demyelinating neuropathy for an antigen shared between myelin and NK cells. Lancet 1, 711-713.

39) Chou, K.H., Ilyas, A.A., Evans, J.E., Quarles, R.H. and Jungalwala, F.B. (1985) Structure of a glycolipid reacting with monoclonal IgM in neuropathy and with HNK-1. Biochem. Biophys. Res. Commun. 128, 383-388.

40) Ilyas, A.A., Dalakas, M.C., Brady, R.O. and Quarles, R.H. (1986) Sulfated glucuronyl glycolipids reacting with anti-myelin-associated glycoprotein monoclonal antibodies including IgM paraproteins in neuropathy: species distribution and partial characterization of epitopes. Brain Res. 385, 1-9.

41) Miyatani, N., Kohriyama, T., Maeda, Y. and Yu,
R.K. (1990) Sulfated glucuronyl paragloboside in rat brain microvessels. J. Neurochem. 55, 577582.

42) Tokuda, A., Ariga, T., Isogai, Y., Komba, S., Kiso, M., Hasegawa, A., Tai, T. and Yu, R.K. (1998) On the specificity of anti-sulfoglucuronosyl glycolipid antibodies. J. Carbohydr. Chem. 17, 535546.

43) Yamawaki, M., Ariga, T., Bigbee, J.W., Ozawa, H., Kawashima, I., Tai, T., Kanda, T. and Yu, R.K. (1996) Generation and characterization of antisulfoglucuronosyl paragloboside monoclonal antibody NGR50 and its immunoreactivity with peripheral nerve. J. Neurosci. Res. 44, 586-593.

44) Schmitz, B., Schachner, M., Ito, Y., Nakano, T. and Ogawa, T. (1994) Determination of structural elements of the L2/HNK-1 carbohydrate epitope required for its function. Glycoconj. J. 11, 345352.

45) Jessell, T.M., Hynes, M.A. and Dodd, J. (1990) Carbohydrates and carbohydrate-binding proteins in the nervous system. Annu. Rev. Neurosci. 13, 227-255.

46) Rutishauser, U. and Jessell, T.M. (1988) Cell adhesion molecules in vertebrate neural development. Physiol. Rev. 68, 819-857.

47) Kruse, J., Mailhammer, R., Wernecke, H., Faissner, A., Sommer, I., Goridis, C. and Schachner, M. (1984) Neural cell adhesion molecules and myelinassociated glycoprotein share a common carbohydrate moiety recognized by monoclonal antibodies L2 and HNK-1. Nature 311, 153-155.

48) Bollensen, E., Steck, A.J. and Schachner, M. (1988) Reactivity with the peripheral myelin glycoprotein P0 in serum from patients with monoclonal IgM gammopathy and polyneuropathy. Neurology 38, 1266-1270.

49) Snipes, G.J., Suter, U. and Shooter, E.M. (1993) Human peripheral myelin protein-22 carries the L2/HNK-1 carbohydrate adhesion epitope. J. Neurochem. 61, 1961-1964.

50) Weiss, M.D., Dalakas, M.C., Lauter, C.J., Willison, H.J. and Quarles, R.H. (1999) Variability in the binding of anti-MAG and anti-SGPG antibodies to target antigens in demyelinating neuropathy and IgM paraproteinemia. J. Neuroimmunol. 95, 174-184.

51) Shiina, M., Kusunoki, S., Miyazaki, T. and Kanazawa, I. (2001) Variability in immunohistochemistries of IgM M-proteins binding to sulfated glucuronyl paragloboside. J. Neuroimmunol. 116, 206-212.

52) Inoue, M., Kato, K., Matsuhashi, H., Kizuka, Y., Kawasaki, T. and Oka, S. (2007) Distributions of glucuronyltransferases, GlcAT-P and GlcAT-S, and their target substrate, the HNK-1 carbohydrate epitope in the adult mouse brain with or without a targeted deletion of the GlcAT-P gene. Brain Res. 1179, 1-15.

53) Bronner-Fraser, M. (1987) Perturbation of cranial neural crest migration by the HNK-1 antibody. Dev. Biol. 123, 321-331. 
54) Kunemund, V., Jungalwala, F.B., Fischer, G., Chou, D.K., Keilhauer, G. and Schachner, M. (1988) The L2/HNK-1 carbohydrate of neural cell adhesion molecules is involved in cell interactions. J. Cell Biol. 106, 213-223.

55) Martini, R., Xin, Y., Schmitz, B. and Schachner, M. (1992) The L2/HNK-1 carbohydrate epitope is involved in the preferential outgrowth of motor neurons on ventral roots and motor nerves. Eur. J. Neurosci. 4, 628-639.

56) Tucker, G.C., Aoyama, H., Lipinski, M., Tursz, T. and Thiery, J.P. (1984) Identical reactivity of monoclonal antibodies HNK-1 and NC-1: conservation in vertebrates on cells derived from the neural primordium and on some leukocytes. Cell Differ. 14, 223-230.

57) Merkouri, E. and Matsas, R. (1992) Monoclonal antibody BM89 recognizes a novel cell surface glycoprotein of the L2/HNK-1 family in the developing mammalian nervous system. Neuroscience 50, 53-68.

58) Naegele, J.R. and Barnstable, C.J. (1991) A carbohydrate epitope defined by monoclonal antibody VC1.1 is found on N-CAM and other cell adhesion molecules. Brain Res. 559, 118-129.

59) Zhao, Z., Nair, S.M., Chou, D.K., Tobet, S.A. and Jungalwala, F.B. (2000) Expression and role of sulfoglucuronyl (HNK-1) carbohydrate and its binding protein SBP-1 in developing rat cerebral cortex. J. Neurosci. Res. 62, 186-205.

60) Chou, D.E., Cai, H., Jayadevappa, D. and Porush, J.G. (2002) Regional expression of inducible nitric oxide synthase in the kidney stimulated by lipopolysaccharide in the rat. Exp. Physiol. 87, 153-162.

61) Nair, S.M. and Jungalwala, F.B. (1997) Characterization of a sulfoglucuronyl carbohydrate binding protein in the developing nervous system. J. Neurochem. 68, 1286-1297.

62) Das, K.K., Basu, M., Li, Z.X., Basu, S. and Jungalwala, F.B. (1990) Characterization of solubilized GlcAT-1 (UDP-GlcA: nLcOse4Cer beta 1-3 glucuronyltransferase) activity from embryonic chicken brain and its inhibition by Derythro-sphingosine. Indian J. Biochem. Biophys. 27, 396-401.

63) Chou, D.K., Flores, S. and Jungalwala, F.B. (1991) Expression and regulation of UDP-glucuronate: neolactotetraosylceramide glucuronyltransferase in the nervous system. J. Biol. Chem. 266, 17941-17947.

64) Chou, D.K. and Jungalwala, F.B. (1993) Characterization and developmental expression of a novel sulfotransferase for the biosynthesis of sulfoglucuronyl glycolipids in the nervous system. J. Biol. Chem. 268, 330-336.

65) Chou, D.K. and Jungalwala, F.B. (1994) Characterization and developmental expression of lactotriosylceramide: galactosyltransferase for the synthesis of neolactotetraosylceramide in the nervous system. J. Neurochem. 62, 307-314.

66) Chou, D.K. and Jungalwala, F.B. (2001) Regulation of sulfoglucuronyl glycolipid synthesis in the developing rat sciatic nerve. Neurochem. Res. 26, 1231-1235.

67) Das, K.K., Basu, M., Basu, S., Chou, D.K. and Jungalwala, F.B. (1991) Biosynthesis in vitro of GlcA $\beta$ 1-3nLcOse4Cer by a novel glucuronyltransferase (GlcAT-1) from embryonic chicken brain. J. Biol. Chem. 266, 5238-5243.

68) Chou, D.K., Prasadarao, N., Koul, O. and Jungalwala, F.B. (1991) Developmental expression of HNK-1-reactive antigens in rat cerebral cortex and molecular heterogeneity of sulfoglucuronylneolactotetraosylceramide in CNS versus PNS. J. Neurochem. 57, 852-859.

69) Oka, S., Terayama, K., Kawashima, C. and Kawasaki, T. (1992) A novel glucuronyltransferase in nervous system presumably associated with the biosynthesis of HNK-1 carbohydrate epitope on glycoproteins. J. Biol. Chem. 267, 2271122714 .

70) Terayama, K., Seiki, T., Nakamura, A., Matsumori, K., Ohta, S., Oka, S., Sugita, M. and Kawasaki, T. (1998) Purification and characterization of a glucuronyltransferase involved in the biosynthesis of the HNK-1 epitope on glycoproteins from rat brain. J. Biol. Chem. 273, 30295-30300.

71) Shimoda, Y., Tajima, Y., Nagase, T., Harii, K., Osumi, N. and Sanai, Y. (1999) Cloning and expression of a novel galactoside $\beta 1,3$-glucuronyltransferase involved in the biosynthesis of HNK-1 epitope. J. Biol. Chem. 274, 17115-17122.

72) Seiki, T., Oka, S., Terayama, K., Imiya, K. and Kawasaki, T. (1999) Molecular cloning and expression of a second glucuronyltransferase involved in the biosynthesis of the HNK-1 carbohydrate epitope. Biochem. Biophys. Res. Commun. 255, 182-187.

73) Kawashima, C., Terayama, K., Ii, M., Oka, S. and Kawasaki, T. (1992) Characterization of a glucuronyltransferase: neolactotetraosylceramide glucuronyltransferase from rat brain. Glycoconj. J. 9, 307-314.

74) Kakuda, S., Oka, S. and Kawasaki, T. (2004) Purification and characterization of two recombinant human glucuronyltransferases involved in the biosynthesis of HNK-1 carbohydrate in Escherichia coli. Protein Expr. Purif. 35, 111-119.

75) Kakuda, S., Sato, Y., Tonoyama, Y., Oka, S. and Kawasaki, T. (2005) Different acceptor specificities of two glucuronyltransferases involved in the biosynthesis of HNK-1 carbohydrate. Glycobiology 15, 203-210.

76) Yavuz, E., Drouillard, S., Samain, E., Roberts, I. and Priem, B. (2008) Glucuronylation in Escherichia coli for the bacterial synthesis of the carbohydrate moiety of nonsulfated HNK-1. Glycobiology 18, 152-157.

77) Mitranic, M.M., Boggs, J.M. and Moscarello, M.A. (1982) The effect of linoleic acid and benzyl alcohol on the activity of glycosyltransferases of rat liver Golgi membranes and some soluble glycosyltransferases. Biochim. Biophys. Acta 
693, 75-84.

78) Westcott, K.R., Wolf, C.C. and Hill, R.L. (1985) Regulation of $\beta$-D-galactoside $\alpha 2 \rightarrow 3$ sialyltransferase activity. The effects of detergents and lysophosphatidates. J. Biol. Chem. 260, 1310913115.

79) Kakuda, S., Shiba, T., Ishiguro, M., Tagawa, H., Oka, S., Kajihara, Y., Kawasaki, T., Wakatsuki, S. and Kato, R. (2004) Structural basis for acceptor substrate recognition of a human glucuronyltransferase, GlcAT-P, an enzyme critical in the biosynthesis of the carbohydrate epitope HNK-1. J. Biol. Chem. 279, 22693-22703.

80) Terayama, K., Oka, S., Seiki, T., Miki, Y., Nakamura, A., Kozutsumi, Y., Takio, K. and Kawasaki, T. (1997) Cloning and functional expression of a novel glucuronyltransferase involved in the biosynthesis of the carbohydrate epitope HNK-1. Proc. Natl. Acad. Sci. U.S.A. 94, 6093-6098.

81) Mitsumoto, Y., Oka, S., Sakuma, H., Inazawa, J. and Kawasaki, T. (2000) Cloning and chromosomal mapping of human glucuronyltransferase involved in biosynthesis of the HNK-1 carbohydrate epitope. Genomics 65, 166-173.

82) Yamamoto, S., Oka, S., Saito-Ohara, F., Inazawa, J. and Kawasaki, T. (2002) Molecular cloning and genomic analysis of mouse glucuronyltransferase involved in biosynthesis of the HNK-1 epitope. J. Biochem. 131, 337-347.

83) Kitagawa, H., Tone, Y., Tamura, J., Neumann, K.W., Ogawa, T., Oka, S., Kawasaki, T. and Sugahara, K. (1998) Molecular cloning and expression of glucuronyltransferase I involved in the biosynthesis of the glycosaminoglycan-protein linkage region of proteoglycans. J. Biol. Chem. 273, 6615-6618.

84) Imiya, K., Ishizaki, T., Seiki, T., Saito, F., Inazawa, J., Oka, S. and Kawasaki, T. (2002) cDNA cloning, genomic structure and chromosomal mapping of the mouse glucuronyltransferase-S involved in the biosynthesis of the HNK-1 carbohydrate epitope. Gene 296, 29-36.

85) Pedersen, L.C., Darden, T.A. and Negishi, M. (2002) Crystal structure of $\beta$ 1,3-glucuronyltransferase I in complex with active donor substrate UDP-GlcUA. J. Biol. Chem. 277, 21869-21873.

86) Shiba, T., Kakuda, S., Ishiguro, M., Morita, I., Oka, S., Kawasaki, T., Wakatsuki, S. and Kato, R. (2006) Crystal structure of GlcAT-S, a human glucuronyltransferase, involved in the biosynthesis of the HNK-1 carbohydrate epitope. Proteins 65, 499-508.

87) Bakker, H., Friedmann, I., Oka, S., Kawasaki, T., Nifant'ev, N., Schachner, M. and Mantei, N. (1997) Expression cloning of a cDNA encoding a sulfotransferase involved in the biosynthesis of the HNK-1 carbohydrate epitope. J. Biol. Chem. 272, 29942-29946.

88) Nagase, T., Shimoda, Y., Sanai, Y., Nakamura, S., Harii, K. and Osumi, N. (2000) Differential expression of two glucuronyltransferases synthe- sizing HNK-1 carbohydrate epitope in the sublineages of the rat myogenic progenitors. Mech. Dev. 98, 145-149.

89) Ngamukote, S., Yanagisawa, M., Ariga, T., Ando, S. and Yu, R.K. (2007) Developmental changes of glycosphingolipids and expression of glycogenes in mouse brains. J. Neurochem. 103, 2327-2341.

90) Yamamoto, S., Oka, S., Inoue, M., Shimuta, M., Manabe, T., Takahashi, H., Miyamoto, M., Asano, M., Sakagami, J., Sudo, K., Iwakura, Y., Ono, K. and Kawasaki, T. (2002) Mice deficient in nervous system-specific carbohydrate epitope HNK-1 exhibit impaired synaptic plasticity and spatial learning. J. Biol. Chem. 277, 2722727231 .

91) Kohriyama, T., Kusunoki, S., Ariga, T., Yoshino, J.E., DeVries, G.H., Latov, N. and Yu, R.K. (1987) Subcellular localization of sulfated glucuronic acid-containing glycolipids reacting with anti-myelin-associated glycoprotein antibody. J. Neurochem. 48, 1516-1522.

92) Ariga, T., Kusunoki, S., Asano, K., Oshima, M., Asano, M., Mannen, T. and Yu, R.K. (1990) Localization of sulfated glucuronyl glycolipids in human dorsal root and sympathetic ganglia. Brain Res. 519, 57-64.

93) Yu, R.K., Yoshino, H., Yamawaki, M., Yoshino, J.E. and Ariga, T. (1994) Subcellular distribution of sulfated glucuronyl glycolipids in human peripheral motor and sensory nerves. J. Biomed. Sci. 1, 167-171.

94) Yamawaki, M., Ariga, T., Gao, Y., Tokuda, A., Yu, J.S., Sismanis, A. and Yu, R.K. (1998) Sulfoglucuronosyl glycolipids as putative antigens for autoimmune inner ear disease. J. Neuroimmunol. 84, 111-116.

95) Yoshino, H., Maeda, Y., King, M., Cartwright, M.J., Richards, D.W., Ariga, T. and Yu, R.K. (1993) Sulfated glucuronyl glycolipids and gangliosides in the optic nerve of humans. Neurology 43, 408411.

96) Ariga, T., Suetake, K., Nakane, M., Kubota, M., Usuki, S., Kawashima, I. and Yu, R.K. (2008) Glycosphingolipid antigens in neural tumor cell lines and anti-glycosphingolipid antibodies in sera of patients with neural tumors. Neurosignals 16, 226-234.

97) Kanda, T., Yoshino, H., Ariga, T., Yamawaki, M. and Yu, R.K. (1994) Glycosphingolipid antigens in cultured bovine brain microvascular endothelial cells: sulfoglucuronosyl paragloboside as a target of monoclonal $\operatorname{IgM}$ in demyelinative neuropathy [corrected]. J. Cell Biol. 126, 235-246.

98) Kanda, T., Ariga, T., Kubodera, H., Jin, H.L., Owada, K., Kasama, T., Yamawaki, M. and Mizusawa, H. (2004) Glycosphingolipid composition of primary cultured human brain microvascular endothelial cells. J. Neurosci. Res. 78, 141-150.

99) Kanda, T. and Ariga, T. (2001) Glycosphingolipid antigen and blood-nerve barrier. Recent Res. Devel. Lipids 5, 97-105. 
100) Jungalwala, F.B., Chou, D.K., Suzuki, Y. and Maxwell, G.D. (1992) Temporal expression of HNK-1-reactive sulfoglucuronyl glycolipid in cultured quail trunk neural crest cells: comparison with other developmentally regulated glycolipids. J. Neurochem. 58, 1045-1051.

101) Holley, J.A. and Yu, R.K. (1987) Localization of glycoconjugates recognized by the HNK-1 antibody in mouse and chick embryos during early neural development. Dev. Neurosci. 9, 105-119.

102) Chou, D.K. and Jungalwala, F.B. (1996) N-Acetylglucosaminyl transferase regulates the expression of the sulfoglucuronyl glycolipids in specific cell types in cerebellum during development. J. Biol. Chem. 271, 28868-28874.

103) Breidbach, O., Dennis, R., Marx, J., Gorlach, C., Wiegandt, H. and Wegerhoff, R. (1992) Insect glial cells show differential expression of a glycolipid-derived, glucuronic acid-containing epitope throughout neurogenesis: detection during postembryogenesis and regeneration in the central nervous system of Tenebrio molitor L. Neurosci. Lett. 147, 5-8.

104) Sugita, M., Itonori, S., Inagaki, F. and Hori, T. (1989) Characterization of two glucuronic acidcontaining glycosphingolipids in larvae of the green-bottle fly, Lucilia caesar. J. Biol. Chem. 264, 15028-15033.

105) Schwarting, G.A., Jungalwala, F.B., Chou, D.K. Boyer, A.M. and Yamamoto, M. (1987) Sulfated glucuronic acid-containing glycoconjugates are temporally and spatially regulated antigens in the developing mammalian nervous system. Dev. Biol. 120, 65-76.

106) Prasadaro, N., Koul, O., Tobet, S.A., Chou, D.K. and Jungalwala, F.B. (1990) Developmental expression of HNK-1-reactive antigens in the rat cerebellum and localization of sulfoglucuronyl glycolipids in molecular layer and deep cerebellar nuclei. J. Neurochem. 55, 2024-2030.

107) Jungalwala, F.B. (1994) Expression and biological functions of sulfoglucuronyl glycolipids (SGGLs) in the nervous system - a review. Neurochem. Res. 19, 945-957.

108) Prasadarao, N., Tobet, S.A. and Jungalwala, F.B. (1990) Effect of different fixatives on immunocytochemical localization of HNK-1-reactive antigens in cerebellum: a method for differentiating the localization of the same carbohydrate epitope on proteins vs lipids. J. Histochem. Cytochem. 38 1193-1200.

109) Chou, D.K., Schachner, M. and Jungalwala, F.B. (2002) HNK-1 sulfotransferase null mice express glucuronyl glycoconjugates and show normal cerebellar granule neuron migration in vivo and in vitro. J. Neurochem. 82, 1239-1251.

110) Martini, R., Bollensen, E. and Schachner, M. (1988) Immunocytological localization of the major peripheral nervous system glycoprotein $\mathrm{P0}$ and the L2/HNK-1 and L3 carbohydrate structures in developing and adult mouse sciatic nerve. Dev. Biol. 129, 330-338.
111) Mendell, J.R., Sahenk, Z., Whitaker, J.N., Trapp, B.D., Yates, A.J., Griggs, R.C. and Quarles, R.H. (1985) Polyneuropathy and IgM monoclonal gammopathy: studies on the pathogenetic role of anti-myelin-associated glycoprotein antibody. Ann. Neurol. 17, 243-254.

112) Rebai, T., Mhiri, C., Heine, P., Charfi, H., Meyrignac, C. and Gherardi, R. (1989) Focal myelin thickenings in a peripheral neuropathy associated with IgM monoclonal gammopathy. Acta Neuropathol. 79, 226-232.

113) Willison, H.J., Trapp, B.D., Bacher, J.D., Dalakas, M.C., Griffin, J.W. and Quarles, R.H. (1988) Demyelination induced by intraneural injection of human antimyelin-associated glycoprotein antibodies. Muscle Nerve 11, 1169-1176.

114) Kohriyama, T., Ariga, T. and Yu, R.K. (1988) Preparation and characterization of antibodies against a sulfated glucuronic acid-containing glycosphingolipid. J. Neurochem. 51, 869-877.

115) Maeda, Y., Bigbee, J.W., Maeda, R., Miyatani, N., Kalb, R.G. and Yu, R.K. (1991) Induction of demyelination by intraneural injection of antibodies against sulfoglucuronyl paragloboside. Exp. Neurol. 113, 221-225.

116) Yamawaki, M., Vasquez, A., Ben Younes, A., Yoshino, H., Kanda, T., Ariga, T., Baumann, N. and Yu, R.K. (1996) Sensitization of Lewis rats with sulfoglucuronosyl paragloboside: electrophysiological and immunological studies of an animal model of peripheral neuropathy. J. Neurosci. Res. 44, 58-65.

117) Ilyas, A.A., Gu, Y., Dalakas, M.C., Quarles, R.H. and Bhatt, S. (2008) Induction of experimental ataxic sensory neuronopathy in cats by immunization with purified SGPG. J. Neuroimmunol. 193, 87-93.

118) Meier, C., Roberts, K., Steck, A., Hess, C., Miloni, E. and Tschopp, L. (1984) Polyneuropathy in Waldenstrom's macroglobulinaemia: reduction of endoneurial IgM-deposits after treatment with chlorambucil and plasmapheresis. Acta Neuropathol. 64, 297-307.

119) Powell, H.C., Rodriguez, M. and Hughes, R.A. (1984) Microangiopathy of vasa nervorum in dysglobulinemic neuropathy. Ann. Neurol. 15, 386-394.

120) Conn, D.L. and Dyck, P.J. (1984) Angiopathic neuropathy in connective tissue disease. In Peripheral Neuropathy 2nd ed. (eds. Dyck, P.J., Thomas. P.K., Lambert, E.H. and Bunger, R.). W.B. Sanders Co., Philadelphia, pp. 2027-2043.

121) Needham, L.K. and Schnaar, R.L. (1991) Adhesion of primary Schwann cells to HNK-1 reactive glycosphingolipids. Cellular specificity. Ann. N. Y. Acad. Sci. 633, 553-555.

122) Kanda, T., Yamawaki, M., Ariga, T. and Yu, R.K. (1995) Interleukin $1 \beta$ up-regulates the expression of sulfoglucuronosyl paragloboside, a ligand for Lselectin, in brain microvascular endothelial cells. Proc. Natl. Acad. Sci. U.S.A. 92, 7897-7901.

123) Dasgupta, S., Yanagisawa, M., Krishnamurthy, K., 
Liour, S.S. and Yu, R.K. (2007) Tumor necrosis factor- $\alpha$ up-regulates glucuronosyltransferase gene expression in human brain endothelial cells and promotes T-cell adhesion. J. Neurosci. Res. 85, 1086-1094.

124) Dasgupta, S., Silva, J., Wang, G. and Yu, R.K. (2009) Sulfoglucuronosyl paragloboside is a ligand for $\mathrm{T}$ cell adhesion: regulation of sulfoglucuronosyl paragloboside expression via nuclear factor $\kappa \mathrm{B}$ signaling. J. Neurosci. Res. 87, 3591-3599.

125) Lawrence, M.B. and Springer, T.A. (1991) Leukocytes roll on a selectin at physiologic flow rates: distinction from and prerequisite for adhesion through integrins. Cell 65, 859-873.

126) Needham, L.K. and Schnaar, R.L. (1993) The HNK1 reactive sulfoglucuronyl glycolipids are ligands for L-selectin and P-selectin but not E-selectin. Proc. Natl. Acad. Sci. U.S.A. 90, 1359-1363.

127) Huang, K., Geoffroy, J.S., Singer, M.S. and Rosen, S.D. (1991) A lymphocyte homing receptor (Lselectin) mediates the in vitro attachment of lymphocytes to myelinated tracts of the central nervous system. J. Clin. Invest. 88, 1778-1783.

128) Hadden, R.D., Nobile-Orazio, E., Sommer, C., Hahn, A., Illa, I., Morra, E., Pollard, J., Hughes, R.A., Bouche, P., Cornblath, D., Evers, E., Koski, C.L., Leger, J.M., Van den Bergh, P., van Doorn, P. and van Schaik, I.N. (2006) European Federation of Neurological Societies/Peripheral Nerve Society guideline on management of paraproteinaemic demyelinating neuropathies: report of a joint task force of the European Federation of Neurological Societies and the Peripheral Nerve Society. Eur. J. Neurol. 13, 809-818.

129) Comi, G., Roveri, L., Swan, A., Willison, H., Bojar, M., Illa, I., Karageorgiou, C., Nobile-Orazio, E., van den Bergh, P., Swan, T., Hughes, R., Aubry, J., Baumann, N., Hadden, R., Lunn, M., Knapp, M., Leger, J.M., Bouche, P., Mazanec, R., Meucci,
N., van der Meche, F. and Toyka, K. (2002) A randomised controlled trial of intravenous immunoglobulin in IgM paraprotein associated demyelinating neuropathy. J. Neurol. 249, 1370-1377.

130) Mariette, X., Chastang, C., Clavelou, P., Louboutin, J.P., Leger, J.M. and Brouet, J.C. for the IgM-associated Polyneuropathy Study Group (1997) A randomised clinical trial comparing interferon- $\alpha$ and intravenous immunoglobulin in polyneuropathy associated with monoclonal IgM. J. Neurol. Neurosurg. Psychiatry 63, 28-34.

131) Blume, G., Pestronk, A. and Goodnough, L.T. (1995) Anti-MAG antibody-associated polyneuropathies: improvement following immunotherapy with monthly plasma exchange and IV cyclophosphamide. Neurology 45, 1577-1580.

132) Pestronk, A., Florence, J., Miller, T., Choksi, R., Al-Lozi, M.T. and Levine, T.D. (2003) Treatment of $\operatorname{IgM}$ antibody associated polyneuropathies using rituximab. J. Neurol. Neurosurg. Psychiatry 74, 485-489.

133) Rojas-Garcia, R., Gallardo, E., de Andres, I., de Luna, N., Juarez, C., Sanchez, P. and Illa, I. (2003) Chronic neuropathy with IgM anti-ganglioside antibodies: lack of long term response to rituximab. Neurology 61, 1814-1816.

134) Willenborg, D.O. and Parish, C.R. (1988) Inhibition of allergic encephalomyelitis in rats by treatment with sulfated polysaccharides. J. Immunol. 140, 3401-3405.

135) IUPAC-IUB Commission on Biochemical Nomenclature (1977) The nomenclature of lipids. Recommendations (1976) Lipids 12, 455-468.

136) Svennerholm, L. (1964) The Gangliosides. J. Lipid Res. 5, 145-155.

(Received Mar. 29, 2011; accepted May 13, 2011) 


\section{Profile}

Toshio Ariga was born in 1944 in Kanagawa, Japan. He graduated from the Kitasato University in 1966 and received a master's degree from the Pharmaceutical Science of Chiba University in 1969. He received the Doctor of Medical Science (PhD) from the Niigata University in 1983 and the Doctor of Pharmaceutical Science (PhD) from the Chiba University in 1986. In 1969, he moved to the Department of Biochemistry, Faculty of Medicine, University of Tokyo and began studies on the structure of gangliosides under the instruction of Professor Tamio Yamakawa, a pioneer in the structure of gangliosides of erythrocyte membranes (1969-1973). He worked in the Department of Metabolism, Central Research Institute of Sankyo Company, Tokyo (1971-1975) and then the Department of Biomembrane, Tokyo Metropolitan Institute of

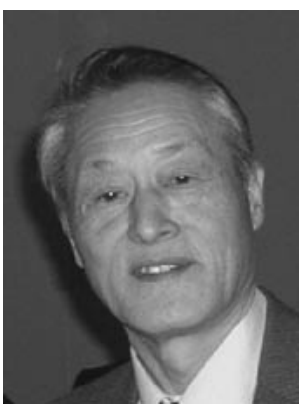
Medical Science, Tokyo (1975-1989). He went to study at the Department of Neurology, Yale University School of Medicine, New Haven, Connecticut, USA under the direction of Professor Robert K. Yu, who is an excellent researcher in structure and metabolism of gangliosides (1983-1985). In 1989, he moved to the Department of Biochemistry, Medical School of Virginia Commonwealth University, Richmond, USA as an Associate Professor (1989-1995) and was promoted to a Professor (1995-1999). In 1998, he became as a Director of the Tsukuba Research laboratories (Tsukuba; 1998-2000) and Clinical Research center (Tokyo; 2001-2006), Eisai Pharmaceutical Company, Japan. After retiring from the Eisai Pharmaceutical Company in 2006, he came to the Institute of Molecular Medicine and Genetics, Medical College of Georgia, Georgia Health Science University, Augusta, Georgia, USA as a Visiting Professor (2006-present). He has engaged in glycoconjugate and neuroscience research for many years. He has contributed significantly to studies on the structure, metabolism, and biological functions of glycoconjugates, especially gangliosides. His research is focused on the pathological role of glycosphingolipids in cancer and neurological diseases, such as Alzheimer's disease, Guillain-Barré Syndrome, and amyotrophic lateral sclerosis. He is also interested in glycosphingolipid markers of neural stem cells and their biological functions in brain development. 